\title{
Secretion of bioactive human insulin following plasmid-mediated gene transfer to non-neuroendocrine cell lines, primary cultures and rat skeletal muscle in vivo
}

\author{
J A M Shaw, M I Delday ${ }^{1}$, A W Hart, H M Docherty, \\ C A Maltin ${ }^{1}$ and K Docherty \\ Department of Molecular and Cell Biology, University of Aberdeen, Institute of Medical Sciences, Foresterhill, Aberdeen AB25 2ZD, UK \\ ${ }^{1}$ Rowett Research Institute, Greenburn Road, Bucksburn, Aberdeen AB2 9SB, UK \\ (Requests for offprints should be addressed to J A M Shaw, Department of Diabetes and Metabolism, Floor 4 William Leech Building, The Medical School, \\ Framlington Place, Newcastle upon Tyne NE2 4HH, UK; Email: jim.shaw@ncl.ac.uk)
}

\begin{abstract}
The objective of these studies was to evaluate human insulin gene expression following intramuscular plasmid injection in non-diabetic rats as a potential approach to gene therapy for diabetes mellitus avoiding the need for immunosuppression. A wild-type human preproinsulin construct and a mutant construct in which PC2/PC3 sites were engineered to form furin consensus sites were evaluated in in vitro transfections of hepatocyte (HepG2) and myoblast (C2C12/L6) cell lines, primary rat myoblasts, and dermal fibroblasts. In vivo gene transfer by percutaneous plasmid injection of soleus muscle \pm prior notexin-induced myolysis was assessed in rats.

In vitro transfection of non-neuroendocrine cell lines and primary cultures with wild-type human preproinsulin resulted in secretion of predominantly unprocessed proinsulin. Employing the mutant construct, there was significant processing to mature insulin (HepG2, 95\%; C2C12, 75\%; L6, 65\%; primary myoblasts, 48\%; neonatal
\end{abstract}

fibroblasts, 56\%; adult fibroblasts, 87\%). In rats aged 5 weeks, circulating human (pro)insulin was detected from 1 to 37 days following plasmid injection and the potential of augmenting transfection efficiency by prior notexin injection was demonstrated (wild-type processing, $87 \%$; mutant, 90\%). Relative hypoglycaemia was confirmed by HbA1C (saline, $5 \cdot 5 \%$; wild type, $5 \cdot 1 \%$; mutant, $5 \cdot 1 \%(P<0 \cdot 05))$. Human (pro)insulin levels and processing (wild-type, 8\%; mutant, 53\%) were lower in rats aged 9 months but relative hypoglycaemia was confirmed by serum glucose at 10 days (saline, $6.4 \mathrm{mmol} / \mathrm{l}$; wild-type, $6.0 \mathrm{mmol} / \mathrm{l}$; mutant, $5 \cdot 4 \mathrm{mmol} / \mathrm{l})$.

In conclusion, prolonged constitutive systemic secretion of bioactive human (pro)insulin has been attained in non-neuroendocrine cells in vitro and in growing and mature rats following intramuscular plasmid injection.

Journal of Endocrinology (2002) 172, 653-672

\section{Introduction}

There is conclusive evidence from major prospective studies in Type 1 and Type 2 diabetes that long term microvascular complications can be prevented by tight glycaemic control (The Diabetes Control and Complications Trial Research Group 1993, UK Prospective Diabetes Study Group 1998). Attainment of this with intensified conventional subcutaneous insulin therapy, or continuous subcutaneous insulin infusion, necessary for all with Type 1 and up to $50 \%$ of those with Type 2 diabetes (Berger 1996), is associated with a threefold increase in hypoglycaemia and necessitates considerable motivation from the diabetic individual in addition to costly health services input. Transplantation of whole vascularised pancreas (Sutherland 1993) and isolated islet cells (Weir \& Bonner-Weir 1997) is becoming increasingly viable, but human cadaveric tissue availability is limited and use of porcine xenografts is complicated by concerns over potential transmission of porcine viral or other infectious agents (Weiss 1998). Genetic engineering approaches to treatment of Type 1 and Type 2 diabetes are thus being explored (Shaw \& Docherty 1999).

Proliferative insulin-secreting beta cell lines have been developed but it has proved difficult to maintain glucose responsivity within the physiological range (Gazdar et al. 1980, Miyazaki et al. 1990). Transfection of other neuroendocrine cell lines with insulin gene constructs resulted in insulin secretion in vivo but this was accompanied by co-secretion of antagonistic hormones such as adrenocorticotrophin (Stewart et al. 1994). Insulin genes have been expressed in non-neuroendocrine cells but these lack the specific endoproteases (PC2 and PC3) necessary for cleavage of proinsulin to fully processed bioactive insulin 
in the beta cell. Post-translational proinsulin processing has been attained following alteration of $\mathrm{PC} 2 / \mathrm{PC} 3$ cleavage sites to form consensus sites for the ubiquitously expressed trans-Golgi network protease, furin. In vivo implantation studies have, however, been complicated by hypoglycaemia due to unregulated cell proliferation with increasing insulin secretion (Kawakami et al. 1992, Falqui et al. 1999).

Allogeneic or xenogeneic cell-based approaches to insulin replacement are dependent on systemic immunosuppression or immunobarrier encapsulation. Immune rejection may be avoided by isolation of accessible, hostderived cells such as myoblasts, ex vivo transfection with gene constructs and subsequent reimplantation by simple intramuscular injection. This has been shown to result in long-term stable secretion of gene products including growth hormone and factor IX into the systemic circulation (Dhawan et al. 1991, Dai et al. 1992). Dermal fibroblasts share a common embryonic origin with myoblasts in the dermamyotome (Wachtler \& Christ 1992), and transdifferentiation to a myogenic lineage has been demonstrated in vitro following transfection with the MyoD myogenic determination factors (Weintraub et al. 1991) and in vivo following simple intramuscular injection (Gibson et al. 1995). This offers the potential of ex vivo transfection and characterisation of easily derived proliferating fibroblasts prior to reimplantation and incorporation into end-differentiated myofibres without further proliferation. Alternatively, endogenous muscle fibres can be transfected in situ offering the potential of foreign expression circumventing both cell culture and immunosuppression.

Intramuscular injection of naked plasmid DNA has been shown, in rodent models, to result in uptake and expression of foreign genes for up to 19 months (Wolff et al. 1992) and prolonged systemic secretion of human proteins such as interferon- $\alpha$ (Horton et al. 1999) and erythropoietin (Tripathy et al. 1996) at therapeutically active concentrations. This technique has been shown to be safe and effective in humans in Phase I/IIa trials of DNA vaccination against malaria employing a plasmid expressing Plasmodium falciparum circumsporozoite protein (Wang et al. 1998). Uptake and expression of plasmid DNA is significantly enhanced during active muscle regeneration induced by prior injection with myolytic agents such as bupivicaine or barium chloride (Wells 1995). Muscle fibre phenotype also appears to play a significant role in determining transfection efficiency, optimal results being attained in muscles such as soleus with a high proportion of type I slow oxidative fibres (Petrof et al. 1996).

The objective of these studies was to assess the potential of muscle-targeted human insulin gene expression as gene therapy for diabetes following intramuscular injection of naked plasmid DNA without immunosuppression. A wild-type human preproinsulin construct and a mutant construct in which PC2 / PC3 sites had been altered by site-directed mutagenesis to form furin consensus sites were initially evaluated in in vitro transfections in hepatocyte and myoblast cell lines, primary rat myoblasts and dermal fibroblasts. In vivo transgene uptake, expression and dissemination were assessed following intramuscular injection of rat soleus muscle with the $\beta$-galactosidase reporter gene. Proinsulin expression, post-translational processing and systemic secretion, together with the effect of prior injection with the myolytic agent, notexin, were evaluated in young and mature non-diabetic rats, following in situ transfection with wild-type and mutant insulin plasmids genes in studies of up to 37 days, with bioactivity determined by serum glucose and glycosylated haemoglobin.

\section{Materials and Methods}

\section{Expression plasmids}

The full-length human preproinsulin cDNA, hppI1, was a gift from Dr G I Bell, University of Chicago, USA. Site-directed mutations in hppI1 were created by overlapping PCR mutagenesis (Higuchi et al. 1988) at PC2 and PC3 cleavage sites to form consensus tetrabasic cleavage sites for furin (hppI4). hppI1 and hppI4 insulin cDNAs were subcloned into an EcoRI site in the pCR3 ampicillin-resistant plasmid (Invitrogen, Carlsbad, CA, USA), downstream of the human cytomegalovirus immediate/early promoter/enhancer $\left(\mathrm{CMV}_{\mathrm{ie}}\right)$ and upstream of a bovine growth hormone polyadenylation signal. The pCR3 plasmid contains also the neomycin phosphotransferase gene under the control of an SV40 viral promoter on a separate expression cassette. hppI1 and hppI4 were sub-cloned into an EcoRI site in the pIRESneo bicistronic expression vector (Clontech, Palo Alto, CA, USA). The expression cassette comprises: $\mathrm{CMV}_{\mathrm{ie}}$ upstream of the human preproinsulin gene, followed by a synthetic intron enhancing mRNA stability (Huang \& Gorman 1990b); the encephalomyocarditis virus internal ribosome entry site, which permits translation of two open reading frames from a single mRNA (Jang et al. 1988); the neomycin phosphotransferase gene; and the bovine growth hormone polyadenylation signal. The pCB7-PACE (furin) hygromycin-resistant plasmid was obtained from Dr J Creemers, University of Leuven, Belgium. The furin (PACE) gene is driven by $\mathrm{CMV}_{\text {ie }}$ with a human growth hormone termination sequence. In the xylE reporter gene, pXylE (provided by Dr A Hayhurst, University of Aberdeen, UK), the xylE gene was cloned downstream of $\mathrm{CMV}_{\text {ie }}$ and upstream of an SV40 late poly-A signal to allow gene expression in eukaryotic cells, utilising the pTZ19U ampicillin-resistant plasmid backbone. XylE is a prokaryotic gene encoding the enzyme, 2,3-dioxygenase, which catalyses conversion of colourless catechol to yellow 2-hydroxymuconic 
semialdehyde, allowing straightforward determination of percentage transfection efficiency (Worsey \& Williams 1977). The reporter gene pCMV- $\beta$ (Clontech) utilises $\mathrm{CMV}_{\text {ie }}$ to drive the $E$. coli $\beta$-galactosidase gene with eukaryotic translation initiation sequences and SV40 polyadenylation signal. Plasmids were grown in DH5a sub-cloning grade E. coli (Gibco BRL, Life Technologies, Paisley, UK) and purified using the Qiagen (Crawley, West Sussex, UK) endotoxin-free maxiprep/megaprep method. Spectrophotometric $A_{260} / A_{280}$ ratios were between 1.75 and 2.0. Plasmid identity and absence of detectable RNA contamination were confirmed by agarose gel electrophoresis following restriction enzyme digestion.

\section{Cell lines}

The human liver cell carcinoma cell line, HepG2 (provided by Dr N Booth, University of Aberdeen, UK), the mouse muscle cell line, C2C12 (supplied by the European Collection of Animal and Cell Cultures, Salisbury, UK), the rat muscle cell line, L6 (provided by Prof. P Cohen, University of Dundee, UK), and a fibroblast cell line engineered to overexpress the human insulin receptor, CHOC16 (obtained from Dr S O'Rahilly, University of Cambridge, UK) were cultured as a monolayer in DMEM supplemented with $10 \%$ fetal calf serum (FCS) and $2 \mathrm{mmol} / \mathrm{l}$ glutamine. DMEM supplemented with $2 \%$ horse serum and $2 \mathrm{mmol} / \mathrm{l}$ glutamine ('fusion medium') was used to induce myoblast fusion to form enddifferentiated multi-nucleated myotubes. All cultures were maintained at $37^{\circ} \mathrm{C}$ in a humid atmosphere containing $5 \% \mathrm{CO}_{2}$.

\section{Use of animals}

Primary cultures were derived from and in vivo studies were performed in Rowett Hooded-Lister rats. All work was carried out within the regulations of the United Kingdom Animal Scientific Procedures Act, 1986.

\section{Establishment of rat myoblasts in primary culture}

Primary myoblast cultures were derived from day-old rat hind limbs comprising soleus, plantaris and gastrocnemius muscle bulks. Fibroblast contamination was minimised by the differential plating technique (Richler \& Yaffe 1970). Cells dispersed mechanically and enzymatically $(0 \cdot 25 \%$ trypsin (w/v) for $45 \mathrm{~min}$ ) were pre-plated for two hours on a tissue culture plate, allowing preferential attachment of more adherent contaminating fibroblasts. Myoblasts remaining in suspension were seeded onto Matrigel basement membrane matrix (Kleinman et al. 1982) and cultured in DMEM supplemented with 20\% FCS, $2 \mathrm{mmol} / \mathrm{l}$ glutamine, $50 \mu \mathrm{g} / \mathrm{ml}$ penicillin/streptomycin and $50 \mu \mathrm{g} / \mathrm{ml}$ fungizone.

\section{Establishment of rat dermal fibroblasts in primary culture}

An area of dorsal shaved skin $\left(1 \mathrm{~cm}^{2}\right)$ was derived from day-old rats (neonatal fibroblasts) or a single 6-month-old rat (adult fibroblasts). Following mechanical and enzymatic dispersion $(0 \cdot 25 \%$ trypsin for $45 \mathrm{~min})$, cells were established in culture in DMEM/20\% FCS/glutamine/ penicillin/streptomycin/fungizone.

\section{In vitro transfection and selection of stable transformants}

In vitro transfections were performed on adherent cells at 60-85\% confluence in 6-well tissue culture plates. For calcium phosphate precipitation, $5 \mu \mathrm{g}$ plasmid DNA were mixed with $12.4 \mu \mathrm{l} 2.5 \mathrm{mmol} / 1$ calcium chloride and diluted to $500 \mu \mathrm{l}$ with sterile water. This was added drop-wise to $100 \mu \mathrm{l} 2 \times$ HBS (Hepes-buffered saline) $\mathrm{pH}$ $7 \cdot 05$, vortexed and incubated at $37^{\circ} \mathrm{C}$ for $30-60 \mathrm{~s}$ to allow formation of a precipitate which was added to cells. Cells were incubated at $37^{\circ} \mathrm{C}$ for $18-24 \mathrm{~h}$, washed with PBS and fresh medium was added.

Trypsinised cells were electroporated in HBS at a density of $10^{7}$ cells $/ \mathrm{ml}(20 \mu \mathrm{g}$ DNA: $400 \mu \mathrm{l}$ cell suspension). In Lipofectamine (Gibco BRL, Life Technologies) liposomal transfections, insulin-containing Optimem (Gibco BRL, Life Technologies) serum-free medium was substituted with DMEM. For each well of a 6-well plate, 1-3 $\mu \mathrm{g}$ DNA and 2-25 $\mu$ l Lipofectamine were employed according to the manufacturer's protocol with a 30-min incubation to allow DNA-liposome complexes to form, and incubation on cells for $5 \mathrm{~h}$, addition of $1 \mathrm{ml}$ DMEM containing twice the normal serum concentration, incubation at $37^{\circ} \mathrm{C}$ for a further $18 \mathrm{~h}$, after which the medium was aspirated and fresh serum-supplemented medium added. In 'Lipofectamine PLUS' transfections 0.5-2 $\mu \mathrm{g}$ DNA in $100 \mu$ DMEM were preincubated for $15 \mathrm{~min}$ at room temperature with 4-10 $\mu$ l'PLUS' reagent (Gibco $\mathrm{BRL}$ ) prior to mixing with $2-16 \mu \mathrm{l}$ Lipofectamine and incubation for $30 \mathrm{~min}$. Incubation on cells was for $3 \mathrm{~h}$ with the protocol otherwise as described above. In selected studies, the lysosomal enzyme inhibitor $\mathrm{N}$-acetyl-leucineleucine-norleucinal (LLnL), also known as Calpain Inhibitor I (Calbiochem, Nottingham, UK), was added to cells with the transfection mixture.

In 'Superfect' transfections, for each well of a 6-well plate, $2 \cdot 5 \mu \mathrm{g}$ DNA and $15 \mu \mathrm{l}$ Superfect (Qiagen) were combined and incubated at room temperature for $15 \mathrm{~min}$ to allow complexes to form. Following incubation on cell monolayer for $3 \mathrm{~h}$ at $37^{\circ} \mathrm{C}$, medium was aspirated, cells washed in PBS and fresh serum-supplemented 
growth medium was added with a further 18-h incubation, aspiration of medium and addition of fresh serum-supplemented medium.

Cells undergoing selection were cultured in growth medium supplemented with $1 \mathrm{mg} / \mathrm{ml}$ G418 (Gibco BRL). Resistant colonies were selected, harvested with a micro-pipette tip, transferred into 24-well plates, maintained in medium containing G418 and allowed to proliferate.

\section{Catechol staining of $p X y l E$ transfected cultured cells}

Freshly prepared catechol $(200 \mu \mathrm{l} ; 20 \mathrm{mmol} / \mathrm{l}$ in PBS) was added to the medium in each well of a 6 -well plate. Following incubation for $30 \mathrm{~min}$ at $37^{\circ} \mathrm{C}$, cells expressing the XylE gene stained yellow. Cells were counted in 5 microscope fields at $\times 200$ magnification with positive staining cells expressed as a percentage of the total.

\section{Immunocytochemical staining of cultured cells}

Following fixing (5\% acetic acid in ethanol for $10 \mathrm{~min}$ at room temperature and at $-20{ }^{\circ} \mathrm{C}$ for $20 \mathrm{~min}$ ), nonspecific antibody binding was blocked with 5\% nonimmune goat or rabbit serum/1\% BSA. Primary antibody $(250 \mu \mathrm{l})(3 \mathrm{~B} 1$ mouse monoclonal anti-human insulin (provided by Prof. C N Hales, University of Cambridge, UK) $1 / 300$, mouse monoclonal anti-porcine desmin 1/50 (Sigma, Poole, Dorset, UK), or goat anti-human vimentin (Sigma) 1/50) was applied to cells (1 h at room temperature). Control cells were treated with non-immune serum from the species in which the primary antibody was raised, diluted to the same concentration. Secondary antibody $(250 \mu \mathrm{l})$ (rabbit anti-mouse tetramethylrhodamine isothiocyanate (TRITC) for insulin primary $1 / 300$, rabbit antimouse TRITC for desmin primary $1 / 100$, monoclonal mouse anti-goat IgG fluorescein isothiocyanate (FITC) for vimentin primary $1 / 100)$ was applied to cells (40 min at room temperature). 4,6-Diamidino-2-phenyl indole (DAPI-blue) nuclear stain $(250 \mu \mathrm{l} ; 1 \mu \mathrm{g} / \mathrm{ml}$ in SSC) was applied to cells (2 min at room temperature). Coverslips were mounted in Vectashield aqueous mounting medium with imaging by digital fluorescence microscopy.

\section{In vivo gene transfer}

Post-weaned male Rowett Hooded-Lister rats aged five weeks (other than in the final reported study performed in mature rats aged 9 months) were divided into weightmatched groups, group-housed and established on a semisynthetic nutritionally adequate diet (Pullar \& Webster 1979). Animals were weighed daily. In selected groups, percutaneous injection of the left soleus muscle with $25 \mu \mathrm{l}$ notexin (Sigma) in PBS at a concentration of $1 \mu \mathrm{g} / 100 \mathrm{~g}$ animal weight was performed using a disposable plastic 1-ml syringe with $25 \mathrm{G}$ needle under halothane anaes- thesia. With the animal in the right lateral position and the hind limb in full extension, an entry site antero-lateral to the Achilles tendon was marked, the needle was advanced $10 \mathrm{~mm}$ parallel to muscle fibres from the distal tendinous insertion into the centre of the soleus muscle bulk and the injection administered. Five days later, plasmid DNA at a concentration of $1 \mu \mathrm{g} / \mu \mathrm{l}$ in normal saline $(\mathrm{NaCl}$ $150 \mathrm{mmol} / \mathrm{l}$ ) was injected employing the same technique under halothane anaesthesia. Control animals were injected with the same volume of normal saline. Blood samples were obtained by initial transverse section of tail vessels during general anaesthesia and subsequently by daily scab removal without restraint for glucose assay $(2.5 \mu \mathrm{l}$ whole blood) by a Precision $\mathrm{G}$ automated glucometer (Medisense, Birmingham, UK) following standardisation with $2.5 \mathrm{mmol} / 1, \quad 5.2 \mathrm{mmol} / 1$ and $17 \cdot 2 \mathrm{mmol} / 1$ control glucose solutions. Blood samples $(200 \mu \mathrm{l})$ were obtained weekly by tail bleeding. Animals were killed by a Schedule 1 method with terminal blood sampling. HbA1C analysis was performed on whole blood by a Primus CLC385 automated analyser, employing boronate affinity separation and high-performance liquid chromatography (Tames et al. 1990, Weykamp et al. 1995). Left and right hind limb soleus, plantaris and gastrocnemius muscles, heart, lungs, kidneys, spleen and pancreas were dissected and frozen in liquid nitrogen for subsequent insulin extraction overnight in $1 \mathrm{ml}$ acid/ ethanol $(7.5 \mathrm{ml}$ concentrated hydrochloric acid; $370 \mathrm{ml}$ in 95\% ethanol) following homogenisation, or were mounted on cork blocks and snap-frozen in liquid nitrogen following application of embedding compound (Tissuetek OCT, Agar Scientific, Stansted, Essex, UK).

\section{$\beta$-Galactosidase staining}

Serial transverse sections were cut at $10 \mu \mathrm{m}$ in a cryostat from 10 equally spaced sites along the length of the muscle or dissected organ. Sections were fixed in 4\% paraformaldehyde $/ 0.25 \%$ glutaraldehyde in PBS for $4 \mathrm{~min}$ at $4{ }^{\circ} \mathrm{C}$, washed in PBS and stained in a solution of $1 \mathrm{mM}$ 5-bromo-4-chloro-3-indolyl $\beta$-D-galactoside (X-gal), $5 \mathrm{mM}$ potassium ferricyanide, $5 \mathrm{mM}$ potassium ferrocyanide, $2 \mathrm{mM}$ magnesium chloride in PBS for $16 \mathrm{~h}$ at $37^{\circ} \mathrm{C}$. After washing in PBS, slides were counterstained in alcoholic eosin, dehydrated in ethanol and mounted in DPX (Agar Scientific). Alternatively, serial non-fixed sections were stained with haematoxylin and eosin.

\section{1 and 1014 insulin RIA}

Harvested tissue culture medium; cells lysed in NP40 buffer $(50 \mathrm{mmol} / 1$ Tris- $\mathrm{HCl}, \mathrm{pH} 8 \cdot 0,120 \mathrm{mmol} / 1 \mathrm{NaCl}$, $0 \cdot 5 \%$ nonidet $\mathrm{P}-40,50 \mathrm{mmol} / 1 \mathrm{NaF}, 10 \mu \mathrm{g} / \mathrm{ml}$ leupeptin, $10 \mu \mathrm{g} / \mathrm{ml}$ aprotonin, $10 \mu \mathrm{g}$ PMSF); or tissue insulin extracts were assayed in duplicate by in-house RIA using a 'non-specific' anti (pro)insulin antibody (1011) to 
measure total insulin-like immunoreactivity (ILI), or a 'specific' antibody (1014) to measure fully processed insulin. Antibodies (Linco Research, Biogenesis, Poole, UK) were polyclonal raised against human (pro)insulin in guinea pig. Minimum detectable concentration of human insulin with the 1011 antibody was $0.08 \mathrm{ng} / \mathrm{ml}$. Mean intra-assay and interassay coefficients of variation were $3.5 \%$ and $5.5 \%$ respectively. Minimum detectable concentration of human insulin with the 1014 antibody was $0.08 \mathrm{ng} / \mathrm{ml}$. Mean intra-assay and interassay coefficients of variation were $3 \cdot 8 \%$ and $6 \%$ respectively.

\section{Gel exclusion chromatography}

Ten grams Bio-gel P30 polyacrylamide beads, swollen overnight in column buffer $(50 \mathrm{mM}$ phosphate buffer $\mathrm{pH}$ 6.8 containing $0.5 \%(\mathrm{w} / \mathrm{v})$ BSA and $0.02 \%(\mathrm{w} / \mathrm{v})$ sodium azide) were packed into a $1 \mathrm{~cm} \times 120 \mathrm{~cm}$ Bio-Rad chromatography column. Compounds $>30 \mathrm{kDa}$ in size are excluded from the column with the passage of smaller compounds being increasingly impeded as size decreases. Samples $(0 \cdot 5-1 \mathrm{ml})$ were applied to the column followed by column buffer with $100 \times 1 \mathrm{ml}$ eluted fractions collected and assayed by 1011 RIA. The column was calibrated with dextran blue, which does not interact with the column, as a measure of void volume $\left(\mathrm{V}_{0}\right)$, potassium dichromate as a measure of total volume $\left(\mathrm{V}_{1}\right)$, and standard preparations of human proinsulin/insulin to determine respective elution fractions for these species.

\section{Insulin bioassay}

Conditioned medium harvested from stably transfected cells was diluted to give 1011 RIA ILI of $100 \mathrm{ng} / \mathrm{ml}$ and used to stimulate a fibroblast cell line engineered to overexpress the human insulin receptor (CHOC16). Cell lysates were immunoprecipitated with an insulin-receptor antibody (provided by Dr S O'Rahilly, University of Cambridge, UK). Western analysis of the immunoprecipitates was carried out using a mouse antiphosphotyrosine antibody. Levels of phosphorylation were directly compared with those obtained with standard insulin $(100 \mathrm{ng} / \mathrm{ml})$ and unconditioned DMEM \pm FCS.

\section{ELISA for serum human insulin, proinsulin, total insulin and C-peptide}

Human insulin in rat serum was assayed by an ELISA specific for fully processed human insulin with no crossreactivity with rat insulin, rat proinsulin, or human proinsulin. Intra-assay and interassay coefficients of variation for human insulin at a concentration of $125 \mathrm{pmol} / \mathrm{l}$ were $5 \cdot 3 \%$ and $5 \cdot 6 \%$ respectively. Minimum detectable concentration of human insulin was $1 \mathrm{pmol} / \mathrm{l}$. Human proinsulin in rat serum was assayed by specific ELISA with no cross-reactivity with rat (pro)insulin, human insulin or human C-peptide. The 32-33 and des 31,32 split forms of proinsulin showed no cross-reactivity but $65-66$ and des 64,65 split forms were detectable with $50-60 \%$ crossreactivity. Intra-assay and interassay coefficients of variation for human proinsulin at a concentration of $7 \mathrm{pmol} / 1$ were $4.3 \%$ and $6 \cdot 8 \%$ respectively. Minimum detectable concentration of human proinsulin was $0.5 \mathrm{pmol} / 1$. Total (human+rat) (pro)insulin in rat serum was determined by ELISA with $100 \%$ cross-reactivity with rat I and II insulin, $70 \%$ cross-reactivity with human proinsulin, 160\% crossreactivity with human insulin and $0 \%$ cross-reactivity with human C-peptide. Intra-assay and interassay coefficients of variation for rat insulin at a concentration of $100 \mathrm{pmol} / 1$ were $2 \cdot 0 \%$ and $3 \cdot 3 \%$ respectively. Minimum detectable concentration of rat insulin was $12 \mathrm{pmol} / \mathrm{l}$. Circulating human C-peptide was assayed by specific ELISA with $0 \%$ cross-reactivity with rat C-peptide, human/rat proinsulin or insulin. Intra-assay and interassay coefficients of variation for human C-peptide at a concentration of $60 \mathrm{pmol} / 1$ were $3 \cdot 2 \%$ and $7 \cdot 3 \%$ respectively. Minimum detectable concentration of human C-peptide was $16.7 \mathrm{pmol} / 1$. All assays were performed in duplicate. All ELISA kits were obtained from Immunodiagnostic Systems Limited, Newcastle, UK.

\section{Statistical analysis}

Values are reported as means \pm S.E.M. Data were analysed by ANOVA with post-hoc assessment for least significant difference. $P<0 \cdot 05$ was accepted as statistically significant.

\section{Results}

Site-directed mutagenesis and sub-cloning to generate wild-type and mutant human insulin plasmids

Wild-type insulin plasmids were constructed from a $511 \mathrm{bp}$ full-length human preproinsulin cDNA comprising a short $5^{\prime}$ untranslated sequence, complete preproinsulin coding region and $3^{\prime}$ untranslated sequence including a 41 base pair (bp) polyadenylation tail. This codes for the complete human preproinsulin polypeptide chain which, following cleavage of the amino-terminal signal peptide by signal peptidase, yields proinsulin (Fig. 1A).

To assess the potential for augmenting insulin processing in cells of non-neuroendocrine origin, a mutant insulin cDNA, hppI4, was constructed by site-directed mutagenesis in which PC2 and PC3 cleavage sites were altered to form consensus tetrabasic cleavage sites (Arg-Lys-ArgArg) for the ubiquitous TGN protease, furin (Fig. 1B). Sequence analysis of the $360 \mathrm{bp}$ DNA fragment generated by overlapping PCR mutagenesis confirmed the presence of the three intended mutations at the B chain/C-peptide junction, the two intended mutations at the C-peptide/ $\mathrm{A}$ chain junction, and a single silent mutation. 

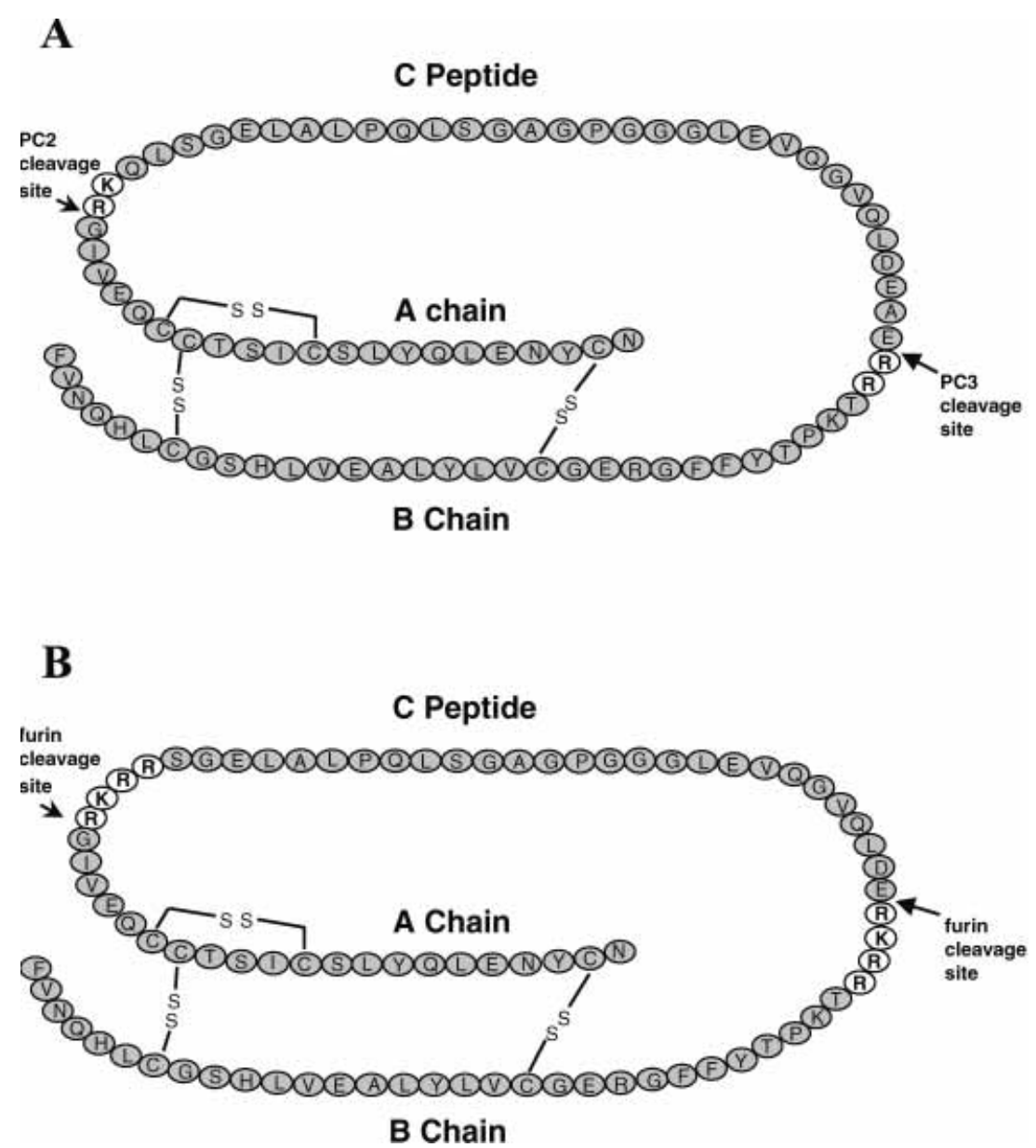

Figure 1 Gene product of hppl1 (A) and hppl4 (B) following cleavage of preproinsulin by signal peptidase.

Wild-type (hppI1) and mutant (hppI4) insulin cDNAs were cloned downstream of the human immediate/ early CMV promoter in pCR 3 and pIRES plasmids to yield pCR3-hppI1, pCR3-hppI4, pIRES-hppI1 and pIRES-hppI4.

Stable transduction of non-neuroendocrine cell lines with wild-type and mutant insulin plasmids

To assess the potential for insulin expression, processing and secretion following transgene expression in nonneuroendocrine cells, stable transfections of the human hepatocyte cell line, HepG2, the mouse myoblast cell line, $\mathrm{C} 2 \mathrm{C} 12$, and the rat myoblast cell line, L6, with wild-type and mutant insulin constructs were performed (Fig. 2). Secretion of human (pro)insulin by transfected cells was measured by RIA of harvested cell medium employing the 'non-specific' insulin antibody, 1011. This exhibited 75\% cross-reactivity with human proinsulin compared with mature insulin, $100 \%$ cross-reactivity with des 31,32 proinsulin, 16\% cross-reactivity with des 64,65 proinsulin, and $45 \%$ cross-reactivity with rat insulin (data not shown). Processing to mature insulin was determined using the 'specific' insulin antibody, 1014, which exhibited $<1 \%$ cross-reactivity with human proinsulin, des 31,32 proinsulin, or 32-33 split proinsulin, 16\% cross-reactivity with des 64,65 proinsulin, and $45 \%$ cross-reactivity with 65-66 split proinsulin in comparison with 100\% cross-reactivity with fully processed human insulin.

HepG2 cells stably transfected with pCR3-hppI1 (HepG2 ins1 clones) secreted up to $0.026 \mathrm{~g}$ of insulin-like immunoreactivity (ILI) $/ 10^{6}$ cells over a 24 -h period, of which, typically, $<2 \%$ reacted with the insulin specific antibody (Fig. 2A). Total ILI in the media from HepG2 cells stably transfected with pCR3-hppI4 (HepG2 ins4 clones) was consistently lower (e.g. $0.004 \mathrm{~g}$ per $10^{6}$ cells per $24 \mathrm{~h}$ ). Up to $100 \%$ of ILI secreted by the HepG2 ins 4 clones cross-reacted with the specific human insulin antiserum (1014) (Fig. 2A). Stable co-transfection with pCR3-hppI4 and the furin plasmid, pCB7-PACE, 

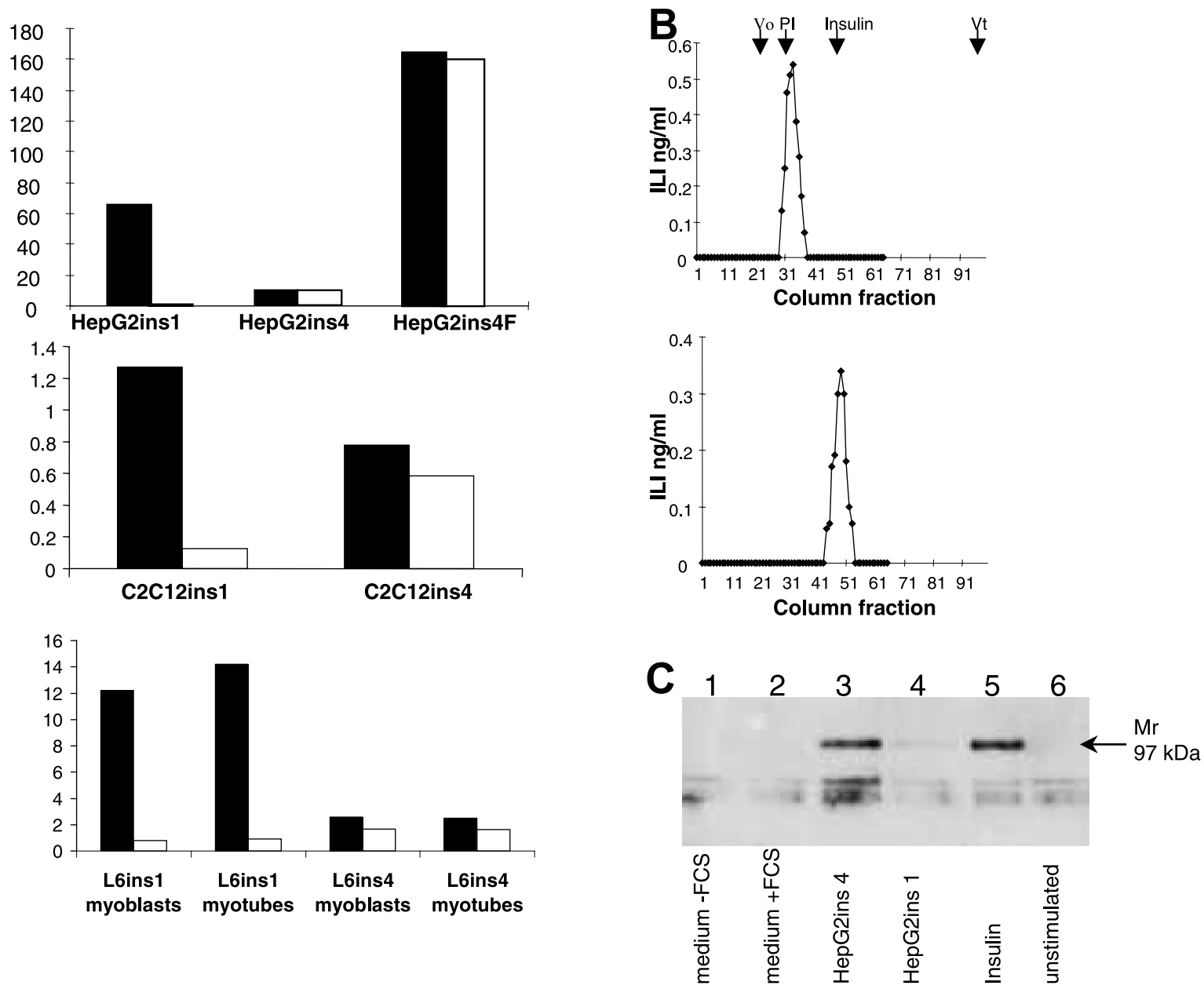

Figure 2 Expression of bioactive insulin in non-neuroendocrine cell lines. (A) HepG2 cells were stably transfected with calcium phosphate employing pCR3-hppl1 (HepG2 ins1), pCR3-hppl4 (HepG2 ins4), and pCR3-hppl4+pCB7-PACE (HepG2 ins4F). C2C12 cells were stably transfected with $1 \mu \mathrm{g}$ DNA/5 $\mu$ l Lipofectamine employing pCR3-hppl1 (C2C12 ins 1 ) and pCR3-hppl4 (C2C12 ins4). L6 cells were stably transfected by electroporation with pIRES-hppl1 (L6 ins1) and pIRES-hppl4 (L6 ins4). Media were collected with RIA using 1011 (black bars) and 1014 (white bars). Results are expressed as means of duplicate RIA determinations, and are representative of at least five separate experiments. (B) Bio-Gel P30 chromatography of conditioned media from HepG2 ins1 and HepG2 ins4 cells. Conditioned media $(0 \cdot 5 \mathrm{ml})$ from HepG2 ins1 (top panel) and HepG2 ins4 cells (lower panel) were applied to a Bio-Gel P30 column with 100 consecutive 1-ml fractions eluted and assayed by 1011 RIA. Calibration demonstrated Vo at fraction 22 and Vt at fraction 96 . PI and Insulin represent peak elution of standard human proinsulin and insulin respectively. (C) Western blot analysis of the phosphorylated insulin receptor of Chinese hamster ovary $(\mathrm{CHOCl6})$ cells stimulated by conditioned media from a HepG2 ins1 and a HepG2 ins4 (HepG2 ins4F.159) clone in comparison to standard human insulin.

resulted in increased ILI secretion (Fig. 2A). In one extensively characterised clone (HepG2 ins4F.159), secretion of $0.05 \mathrm{~g}$ mature insulin $/ 10^{6}$ cells in a $24-\mathrm{h}$ period has been attained.

Stable transfections of the myoblast cell line, C2C12, with pCR3-hppI1 and pCR3-hppI4 resulted in maximal total ILI secretion, determined by non-specific RIA (1011) of $1.27 \mathrm{ng} / \mathrm{ml} / 24 \mathrm{~h}$ and $0.78 \mathrm{ng} / \mathrm{ml} / 24 \mathrm{~h}$ respectively, with levels consistently lower in transfections with the mutant construct. In wild-type transfections, $10 \%$ of total ILI was detected using the insulin specific antibody 1014
(Fig. 2A). Seventy-five percent cross-reactivity with specific antibody was measured in clones stably expressing pCR3-hppI4.

The highest levels of insulin secretion in the L6 myoblast cell line were attained following stable transfection with pIRES as opposed to pCR3 plasmids. Overall, secreted ILI was lower in mutant-transfected clones. Specific insulin antibody cross-reactivities were $<10 \%$ in wild-type clones and $65 \%$ in mutant clones. Induction of myotube formation in stably transfected L6 myoblasts resulted in no significant change in overall 
secreted (pro)insulin levels or insulin processing as determined by non-specific and specific antibodies (Fig. 2A).

There was no evidence of intracellular accumulation of synthesised insulin in wild-type or mutant transfections of HepG2, C2C12 or L6 cell lines, intracellular levels in all cases being $<10 \%$ of extracellular concentrations.

\section{Determination of insulin processing in transfected cell by gel exclusion chromatography}

Processing of human (pro)insulin secreted by stably transfected non-neuroendocrine cell lines was further assessed by fractionation of medium according to protein size by gel exclusion chromatography, and measurement of ILI in consecutive fractions by non-specific insulin RIA. Insulinlike material secreted from HepG2 ins1 cells co-eluted with proinsulin, while that from HepG2 ins4 cells coeluted with insulin (Fig. 2B). Co-elution with proinsulin was seen in $\mathrm{C} 2 \mathrm{C} 12$ and L6 myoblasts transfected with hppI1 (data not shown).

\section{Biological activity of insulin-like material secreted by Hep G2 ins cells}

Differential RIA and gel exclusion chromatography indicated that the predominant insulin-like material secreted from HepG2 ins4 clones was mature, native, human insulin with potential for full biological activity. Further assessment of stably transfected HepG2 cells in an insulin receptor phosphorylation bioassay demonstrated equivalent bioactivity to commercial human insulin with conditioned medium from HepG2 ins4F.159, whereas conditioned medium from HepG2 ins1 cells failed to stimulate phosphorylation of the insulin receptor at the same concentration (Fig. 2C).

\section{Characterisation and transfection of rat neonatal myoblasts in primary culture}

The predominance of myogenic cells was confirmed by characteristic bipolar morphology on light microscopy at 3 days following establishment in culture. Greater than $90 \%$ of cells demonstrated positive desmin staining confirming purity of myogenic origin. At 4 days, myoblasts aligned longitudinally and, at 5-7 days, fibres fused to form multi-nucleated myotubes. Fusion of cultured cells to form myotubes and absence of fibroblast overgrowth following prolonged culture provided further evidence of uncontaminated myogenic origin.

Despite optimisation of transfection conditions, percentage transfection efficiency was low with $<5 \%$ of cells expressing transgene as determined by catechol staining in transfections with the pXylE reporter gene (Fig. 3A). Insulin expression in myoblasts transfected with both the wild-type and mutant plasmids was confirmed by positive cytoplasmic insulin immunocytochemical staining at $24 \mathrm{~h}$ post transfection. Positive insulin staining was seen in $<5 \%$ of myoblasts. There were no significant differences in percentage transfection efficiency between pCR3-hppI1, pCR3-hppI4, pIRES-hppI1 and pIRES-hppI4.

Evidence for persistence of foreign gene expression in myotubes was seen in time courses following transfection with pXylE, pCR3-hppI1 or pCR3-hppI4. At $24 \mathrm{~h}$ following transfection, positive staining was confined to myoblasts even in the presence of fused myotubes. At 2 and 3 days post transfection, positive staining was seen predominantly in myotubes suggesting fusion of a transgene-expressing myoblast with other myoblasts to form a myotube maintaining transgene expression. Myotubes themselves were, however, resistant to transfection (Fig. 3A,B).

The highest total ILI was attained in optimised transfections with pIRES as opposed to pCR3 plasmids, with overall levels consistently higher in wild-type in comparison with mutant transfections (Fig. 3C). Persistence of (pro)insulin secretion for 14 days following wild-type and mutant transfection provided further confirmation of transgene expression following myoblast fusion, the whole culture being made up of twitching myotubes at 3 days following completion of transfection. In wild-type transfections, $5 \%$ of total ILI was detected using the insulinspecific antibody 1014 (Fig. 3D). Processing was increased to $24 \%$ in pIRES-hppI1/pCB7-PACE co-transfections and to $48 \%$ following transfection with pIRES-hppI4. There was no evidence of intracellular accumulation of synthesised insulin in wild-type or mutant transfections (Fig. 3E).

Processing of human (pro)insulin secreted by transfected myoblasts was further assessed by gel exclusion chromatography. Comparison of areas under the curve demonstrated $>95 \%$ of secreted ILI co-eluting with proinsulin and $<5 \%$ co-eluting with mature insulin (Fig. 3F).

\section{Characterisation and transfection of rat dermal fibroblasts in primary culture}

Neonatal and adult dermal fibroblasts were identified by characteristic adherent, stellate morphology on light microscopy. Prior to passage, occasional contaminating bipolar cells of myogenic origin were seen. Purity of fibroblast origin following sub-culture was confirmed by absence of fusion to form multinucleated myotubes, even following prolonged culture in 'fusion medium', allowing cells to reach $100 \%$ confluence to promote myotube formation. Further characterisation was performed by immunocytochemical staining for desmin, expressed in both myoblasts and myotubes but absent from fibroblasts (Jones et al. 1990), and vimentin, expressed in fibroblasts and myogenic cells (Stewart 1990). Following subculture, purity of fibroblast origin was confirmed by absence of desmin staining. 

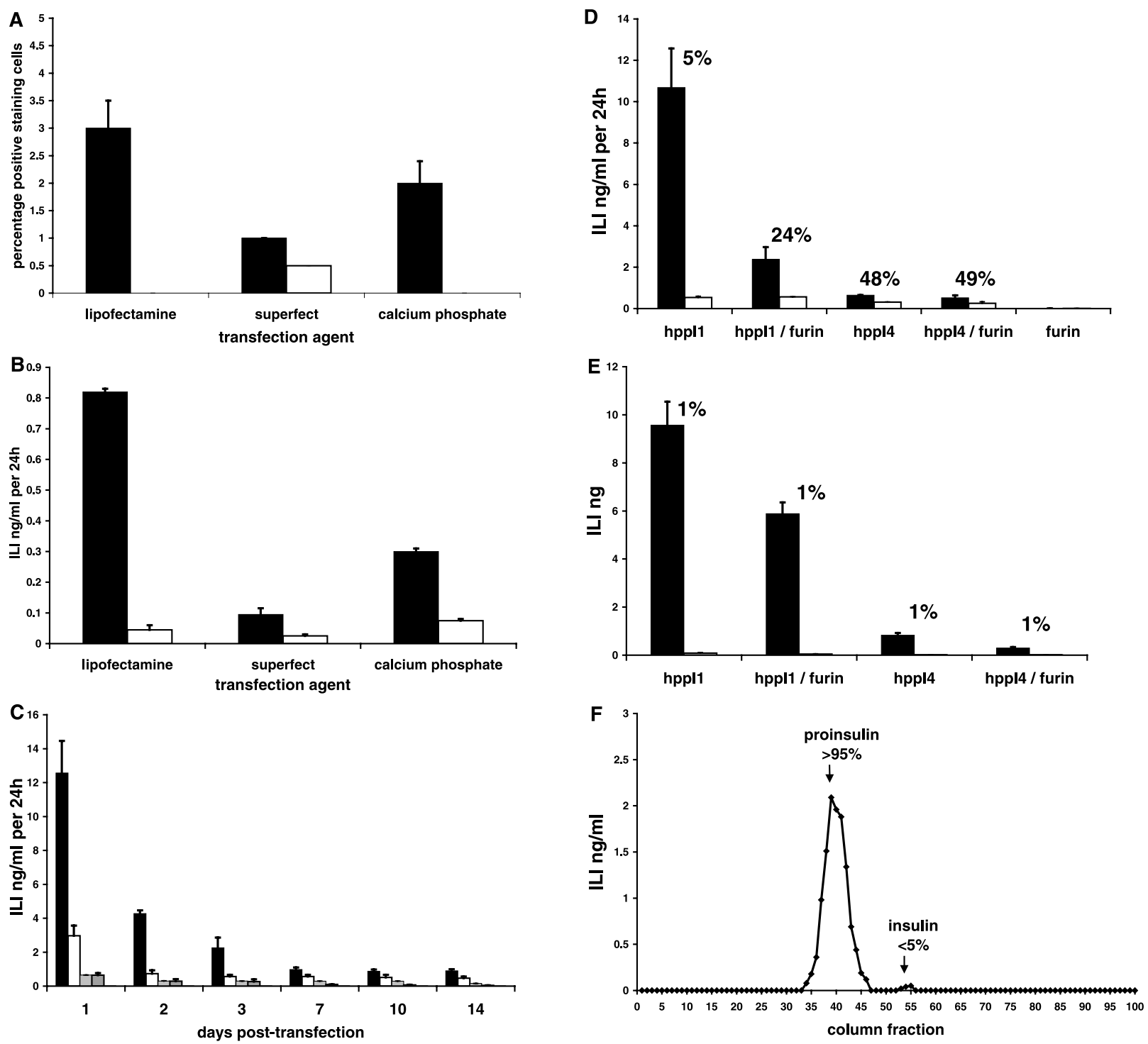

Figure 3 Insulin expression in transfected primary myoblasts. Myoblasts were transfected at a density of $1 \times 10^{6}$ cells/well with $1 \mu \mathrm{g}$ DNA/10 $\mu$ l Lipofectamine with assay of medium by 1011 RIA at 24-h post-transfection unless otherwise stated. Medium was changed $24 \mathrm{~h}$ prior to collection of each sample. Values represent the mean \pm S.E.M. of two transfections assayed in duplicate and are representative of repeated studies. (A, B) Myoblasts (black bars) or fused myotubes (white bars) were transfected with pXylE (A) or pCR3-hppl1 (B) employing Lipofectamine, Superfect or calcium phosphate methods with percentage transfection efficiency determined by catechol staining (A) or 1011 RIA (B). (C) Timecourse of (pro)insulin secretion determined by 1011 RIA following myoblast transfection with pIRES-hppl1 (black bars), pIRES-hppl1/pCB7-PACE (white bars), pIRES-hppl4 (grey bars), pIRES-hppl4/pCB7-PACE (striped bars) or pCB7-PACE (no detectable insulin-like immunoreactivity (ILI) at any time-point). (D) Insulin processing in transfected cells determined by 1011 RIA (black bars) and 1014 RIA (white bars) of medium at $24 \mathrm{~h}$ post-transfection. Percentages refer to degree of proinsulin to insulin processing (specific ILI/non-specific ILI $\times 100 \%$ ). (E) Assay of medium (black bars) and cell lysates (white bars) by 1011 RIA following transfection with pIRES-hppl1 or pIRES-hppl $4 \pm$ co-transfection with furin (pCB7-PACE). Percentages refer to intracellular portion of total ILI. (F) Determination of (pro)insulin processing following fractionation by gel exclusion chromatography. Myoblast medium (1 $\mathrm{ml}) 24 \mathrm{~h}$ post pIRES-hppl1 transfection was applied to a Bio-Gel P30 column with 100 consecutive 1-ml fractions eluted and assayed by 1011 RIA. Calibration demonstrated $V_{0}$ at fraction 22 and $V t$ at fraction 96. Proinsulin and insulin represent peak elution of standard human proinsulin and insulin respectively. Comparison of areas under the curve (AUC) demonstrated $>95 \%$ of secreted (pro)insulin as proinsulin and $<5 \%$ as fully processed insulin. 

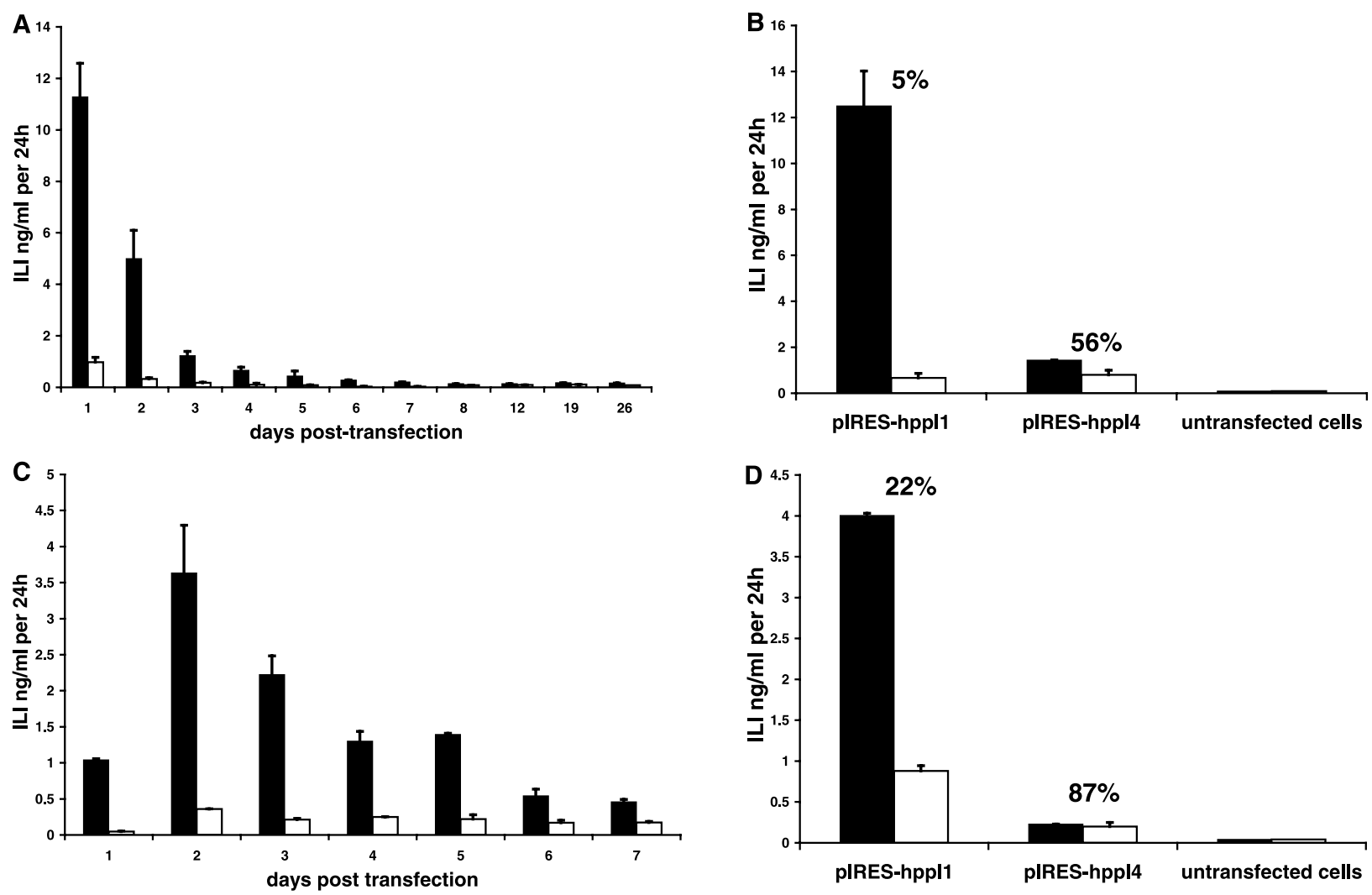

Figure 4 Insulin expression in transfected primary rat fibroblasts. Medium was changed $24 \mathrm{~h}$ prior to collection of each sample. Values represent the mean \pm S.E.M. of two transfections assayed in duplicate and are representative of repeated studies. (A, B) Neonatal rat dermal fibroblasts were seeded at $1 \times 10^{5}$ cells $/ \mathrm{ml}$ and transfected after $24 \mathrm{~h}$ at $85 \%$ confluence. (A) Timecourse of (pro)insulin secretion determined by 1011 RIA following transfection of neonatal fibroblasts with pIRES-hppl1 (black bars) or pIRES-hppl4 (white bars) employing $1 \mu \mathrm{g}$ DNA/10 $\mu$ l Lipofectamine. (B) Insulin processing in neonatal fibroblasts transfected with $2 \mu \mathrm{g}$ pIRES-hppl1/10 $\mu$ l Lipofectamine or $3 \mu \mathrm{g}$ pIRES-hppl4/10 $\mu$ Lipofectamine determined by 1011 RIA (black bars) and 1014 RIA (white bars) of medium at $24 \mathrm{~h}$ post-transfection. Percentages refer to degree of proinsulin to insulin processing (specific ILI/non-specific ILI $\times 100 \%$ ). (C, D) Adult rat dermal fibroblasts were seeded at $5 \times 10^{4}$ cells $/ \mathrm{ml}$ and transfected after $24 \mathrm{~h}$ at $85 \%$ confluence employing $1 \mu \mathrm{g}$ DNA, $6 \mu$ PLUS reagent, $4 \mu \mathrm{l}$ Lipofectamine and $1 \mu \mathrm{M} \mathrm{LLnL}$ in DMSO. (C) Timecourse of (pro)insulin secretion determined by 1011 RIA following transfection with pIRES-hppl1 (black bars) or pIRES-hppl4 (white bars). (D) Insulin processing in adult fibroblasts transfected with pIRES-hppl1 or pIRES-hppl4 determined by 1011 RIA (black bars) and 1014 RIA (white bars) of medium at 24 h post-transfection. Percentages refer to degree of proinsulin to insulin processing (specific ILI/non-specific ILI × $100 \%$ ).

Transient transfections of primary dermal fibroblasts derived from neonatal and adult rats were performed with assessment by non-specific and specific RIA. Despite optimisation of transfection conditions, percentage transfection efficiency was low with a maximum of $5 \%$ of cells expressing transgene as determined by catechol staining in transfections with the pXylE reporter gene and insulin immunocytochemical staining following insulin plasmid transfection. No quantifiable difference in percentage transfection efficiency was demonstrated in comparative transfections with pCR3-hppI1, pCR3-hppI4, pIREShppI1, or pIRES-hppI4 in neonatal or adult fibroblasts.

Lipofectamine was the optimal transfection reagent in neonatal and adult fibroblasts with the highest total ILI attained in transfections with pIRES as opposed to
pCR3 plasmids, and overall levels consistently higher in wild-type in comparison with mutant transfections (Fig. 4A).

One of the factors limiting transfection efficiency in primary fibroblasts may be degradation of plasmid DNA by the action of lysosomal enzymes prior to entering the nucleus (Coonrod et al. 1997). The effect of the lysosomal enzyme inhibitor $\mathrm{N}$-acetyl-leucine-leucine-norleucinal (LLnL) on transfection efficiency in primary adult dermal fibroblasts was assessed, together with the potential for increasing transfection efficiency by pre-complexation of DNA with PLUS reagent (Gibco BRL, Life Technologies). Peak (pro)insulin secretion by transfected adult fibroblasts was seen at 2-3 days in all variations of the Lipofectamine protocol. Precomplexing plasmid DNA 

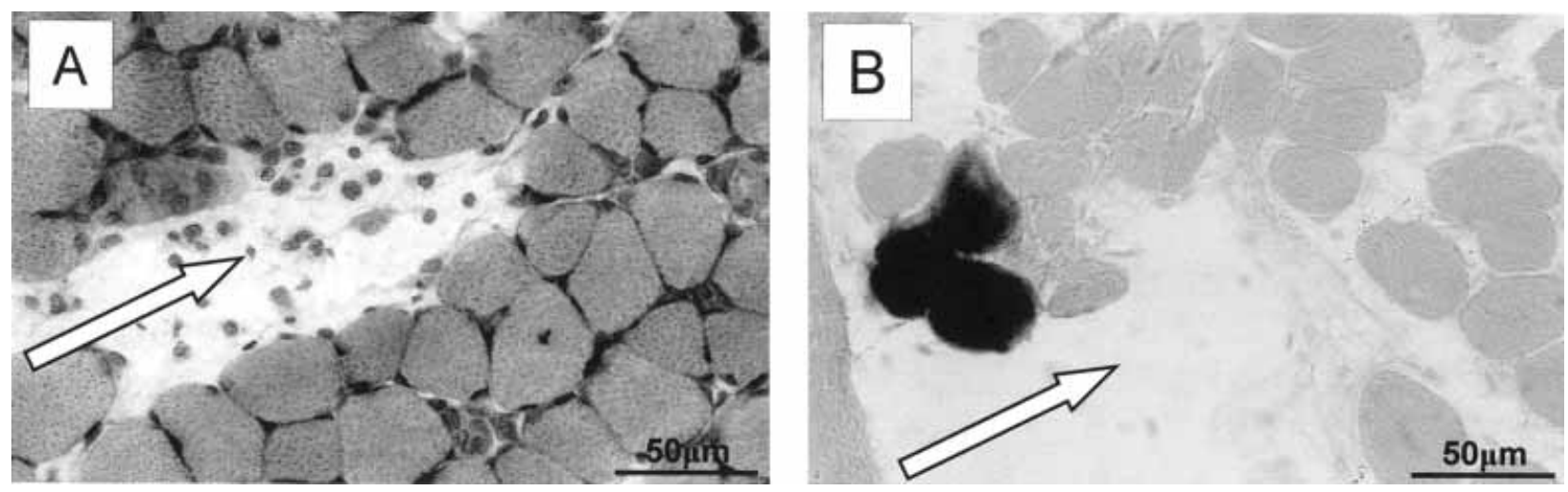

Figure 5 Transverse sections of soleus muscle at $48 \mathrm{~h}$ following plasmid injection. Groups of 8 animals were injected with $50 \mu \mathrm{l}$ pCMV- $\beta$ with 4 control animals receiving $50 \mu \mathrm{l}$ normal saline. Animals were killed at 2, 4, 24 and $48 \mathrm{~h}$. (A) Haematoxylin/eosin stain demonstrating (arrowed) inflammatory cell infiltration at injection site with flanking infiltrated, degenerating myofibre. (B) X-gal/eosin stain demonstrating (arrowed) injection site with flanking dark-staining $\beta$-galactosidase expressing fibres.

with PLUS reagent increased peak (pro)insulin secretion in wild-type and mutant insulin transfections. Addition of LLnL resulted in a further incremental increase in secreted (pro)insulin. Time courses of (pro)insulin secretion following transfection of adult dermal fibroblasts with pIREShppI1 and pIRES-hppI4 under optimised Lipofectamine PLUS conditions including LLnL are demonstrated (Fig. 4C).

Post-translational processing in transfected neonatal fibroblasts (Fig. 4B) and adult fibroblasts (Fig. 4D) was assessed by differential RIA.

\section{$\beta$-Galactosidase expression in muscle}

Reporter gene studies were performed to assess transfection efficiency and localisation of transgene expression following intramuscular injection of plasmid DNA. There were no anaesthetic losses and animals otherwise remained healthy. Intramuscular injection with plasmid or saline was associated with localised infiltration of inflammatory cells at the injection site (Fig. 5A). There was evidence of localised necrosis and subsequent regeneration of surrounding muscle fibres. Transgene expression in plasmidinjected soleus muscles was confirmed by positive $\beta$-galactosidase staining at 24 and $48 \mathrm{~h}$ (Fig. 5B). Staining was confined to fibres flanking the injection site, with $<1 \%$ of fibres taking up and expressing foreign DNA. No $\beta$-galactosidase-positive fibres were detected in surrounding plantaris or gastrocnemius muscles and no positive staining was seen in contralateral hind limb muscles, heart, lungs, kidneys, spleen or pancreas. There were no $\beta$-galactosidase-positive fibres in saline-injected animals.

\section{Insulin expression in plasmid-injected muscle}

Significant levels of circulating fully processed human insulin were detected by ELISA in the serum of $50 \%$ of animals at 24 and $48 \mathrm{~h}$ following hind limb plasmid injection with pIRES-hppI1 or pIRES-hppI4 (Fig. 6A). Measurable (pro)insulin was detected by non-specific RIA following tissue processing in hind limbs injected with both wild-type and mutant plasmids (Fig. 6B). There was no evidence of serum or tissue human insulin expression in saline-injected animals.

\section{Augmentation of insulin expression by pre-injection with notexin}

Notexin injection was associated with increased myolysis, inflammatory cell infiltration and muscle regeneration (Fig. 7A), although this remained localised to the injection site in soleus muscle with no macroscopic or histological evidence of inflammation in surrounding tissues.

Fifty percent of animals again demonstrated detectable levels of circulating human insulin at $24 \mathrm{~h}$ following injection with the pIRES-hppI1 plasmid alone. In animals pre-injected with notexin, however, mean circulating human insulin was significantly higher and efficiency was increased to $100 \%$ of animals showing detectable serum insulin levels at $24 \mathrm{~h}$ (Fig. 7B). There was no evidence of circulating human insulin in animals injected with saline with or without notexin preinjection.

\section{Study of longer term insulin expression following in vivo transfection with pIRES-hppI1 with or without notexin-induced preinjection myolysis}

There was no detectable circulating human insulin at 7 or 14 days in animals injected with saline with or without pre-injection with notexin. Fifty percent (6 of 12) of animals injected solely with pIRES-hppI1 showed detectable levels of circulating fully processed human insulin at 7 and 14 days. Notexin pre-injection resulted in significantly increased transgene expression with detectable serum 

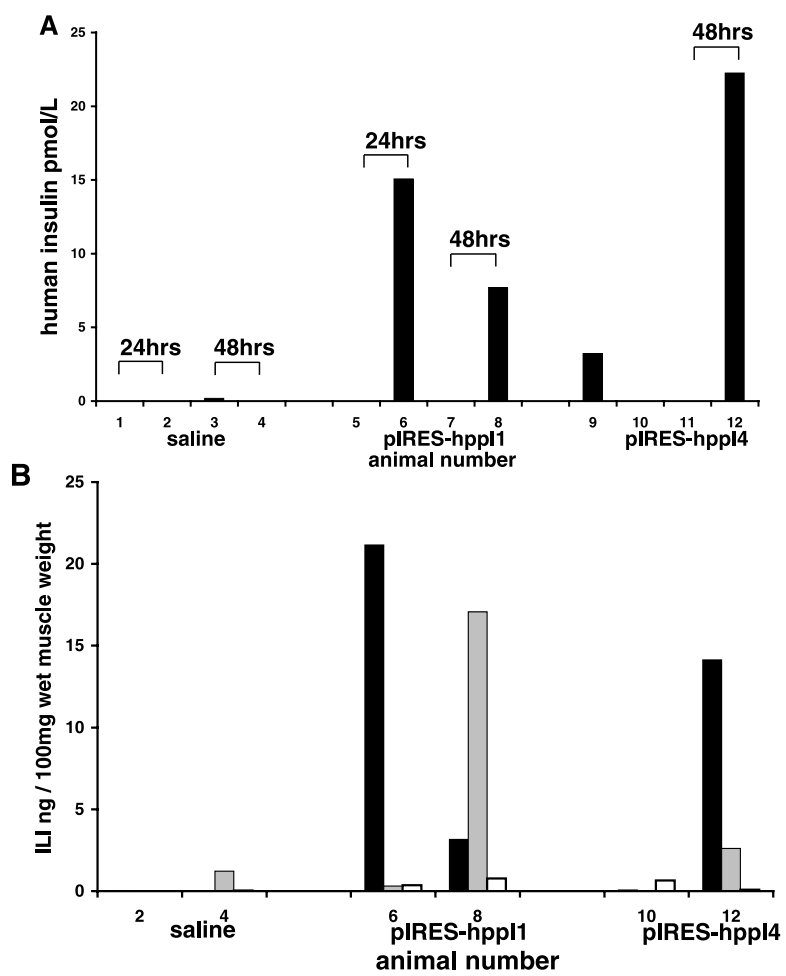

Figure 6 Human insulin expression in muscle and serum following plasmid injection. Four animals were injected with pIRES-hppl1, 4 with pIRES-hppl 4 and 4 with normal saline $(75 \mu$ l per injection $(1 \mu \mathrm{g} / \mu \mathrm{l}))$. Two animals from each group were killed at $24 \mathrm{~h}$ and 2 at $48 \mathrm{~h}$ after injection. In one animal from each group at each time-point, insulin was extracted in acid/ethanol from homogenised soleus, plantaris and gastrocnemius muscles from the injected limb. (A) Serum human insulin determined by ELISA. Each bar refers to a single animal assayed in duplicate. (B) Tissue (pro)insulin estimation by 1011 RIA. Each bar represents a single muscle from an individual rat assayed in duplicate (black bars, soleus; grey bars, plantaris; white bars, gastrocnemius). (Pro)insulin was detected in all hind limbs injected with pIRES-hppl 1 and pIRES-hppl4. Results are representative of three repeated studies.

insulin in $75 \%$ (9 of 12) of animals and higher mean circulating insulin levels at 7 and 14 days (Fig. 8A). Measurement of serum proinsulin by ELISA at 14 days revealed a very high ratio of circulating human insulin to proinsulin in both plasmid-injected groups, indicating significant post-translational processing of skeletal muscle expressed preproinsulin in vivo (Fig. 8B). Circulating human C-peptide levels were detectable in all plasmidinjected animals and were significantly higher than those in control animals. Highest levels were seen following notexin-induced myolytic injury (Fig. 8C). The human C-peptide:(pro)insulin ratio was $1 \cdot 5-2 \cdot 5$, again suggesting complete cleavage of proinsulin leading to equimolar initial concentrations of insulin and C-peptide, with ultimately higher $\mathrm{C}$-peptide levels due to its longer half-life in the peripheral circulation.
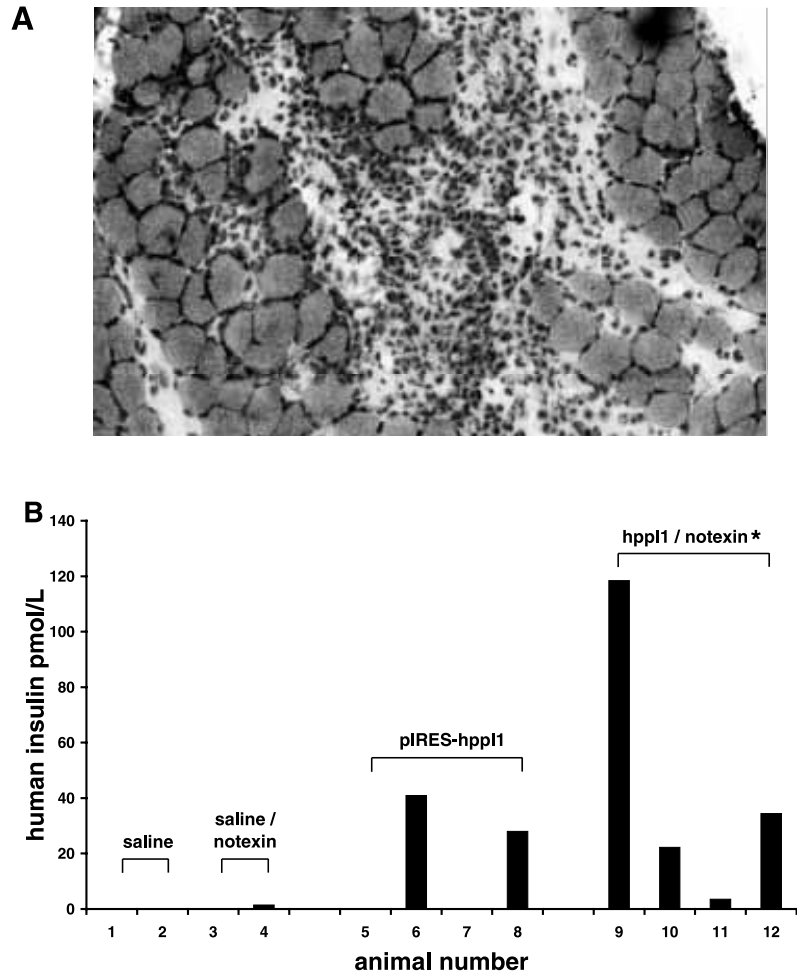

Figure 7 Effect of notexin-induced myolytic injury on muscle histology and serum expression of fully processed human insulin. Eight animals were injected with $75 \mu \mathrm{l}$ pIRES-hppl1 and 4 animals were injected with normal saline. In $50 \%$ of animals from each group this was preceded 5 days earlier by notexin injection at the same site. All animals were killed at $24 \mathrm{~h}$ following plasmid injection. (A) Transverse section of soleus muscle following notexin injection. Haematoxylin/eosin stain at 6 days following notexin injection and $24 \mathrm{~h}$ following plasmid injection demonstrating gross inflammatory cell infiltration at injection site with flanking infiltrated myofibres $(\times 200)$. (B) Serum human insulin determined by ELISA. Each bar refers to a single animal assayed in duplicate. Mean circulating human insulin was significantly higher in the hppl 1 + notexin group $(6 \cdot 2 \mu \mathrm{U} / \mathrm{ml})$ compared with saline \pm notexin controls $(0 \cdot 05 \mu \mathrm{U} / \mathrm{ml}$ ) (ANOVA $\left.{ }^{*} P<0 \cdot 05\right)$. Mean with hppl1 alone $(2 \cdot 3 \mu \mathrm{U} / \mathrm{ml})$.

\section{Insulin bioactivity}

Blood glucose was unaffected by myolytic injury, there being no significant difference between saline control groups with or without notexin injection (mean glucose after saline injection: saline group $7.67 \mathrm{mmol} / \mathrm{l}$; saline/ notexin group $7 \cdot 42 \mathrm{mmol} / \mathrm{l})$. Following plasmid injection, glucose levels fell in both hppI1 groups and animals were allowed access to supplemental sucrose from days $4-7$, as prophylaxis against dangerous hypoglycaemia, following individual animal glucose levels as low as $5 \mathrm{mmol} / \mathrm{l}$ in the plasmid group pre-treated with notexin. No animal displayed any signs of symptomatic hypoglycaemia in this study.

Mean glucose was lower than control at all but one time-point following injection with wild-type plasmid 

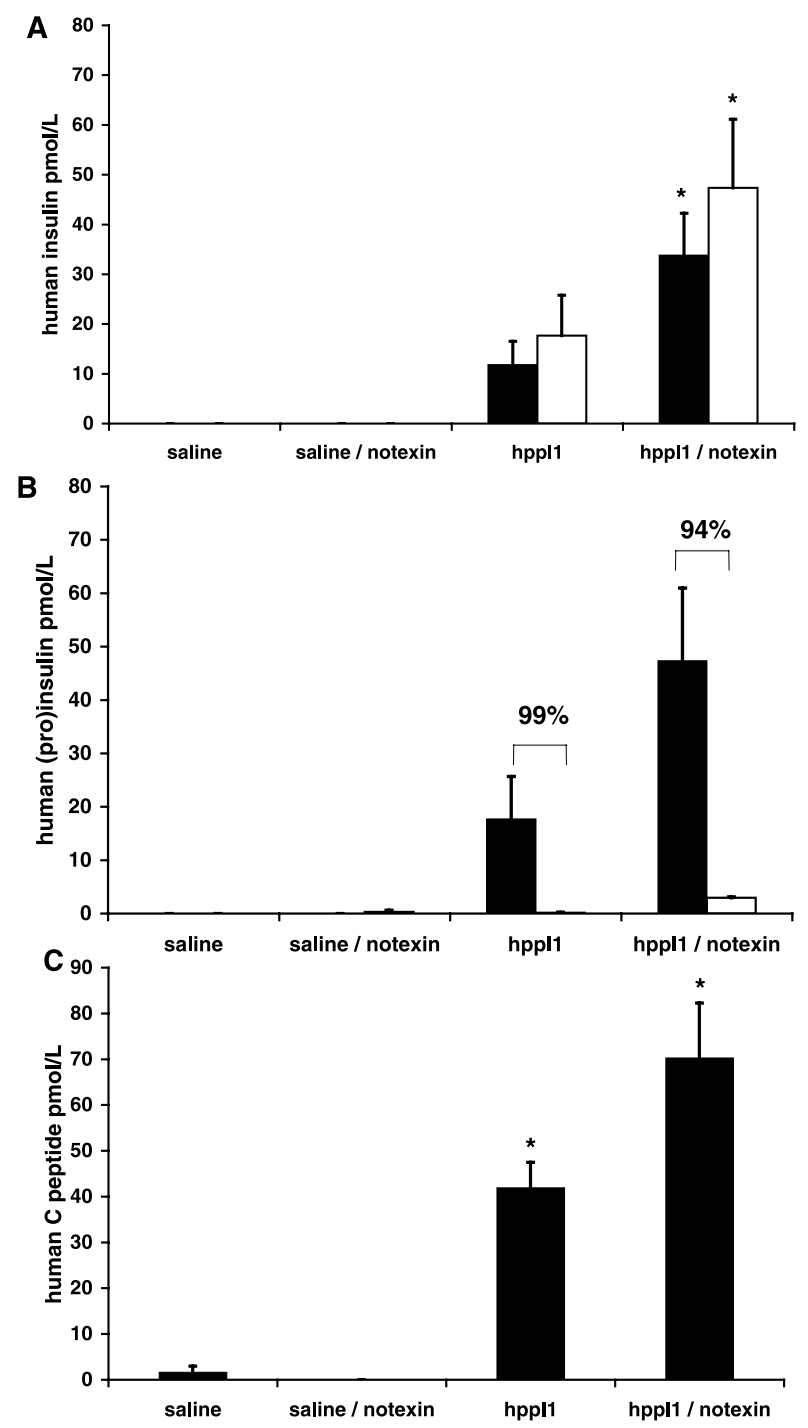

Figure 8 Effect of prior myolytic injury on insulin/C-peptide expression and processing at 14 days following plasmid injection. Notexin was injected 5 days before insulin plasmid/saline. Three animals were injected with $75 \mu \mathrm{l}$ normal saline, 3 with $75 \mu \mathrm{l}$ normal saline preceded by notexin, 12 with $75 \mu$ I pIRES-hppl 1 and 12 with $75 \mu \mathrm{l}$ pIRES-hppl1 preceded by notexin. Blood was sampled for insulin ELISA at 7 days and animals were killed at 14 days following plasmid injection. (A) Serum expression of fully processed human insulin at 7 (black bars) and 14 days (white bars) following plasmid injection. Mean circulating human insulin was significantly higher in the hppl1/notexin group compared with hppl1 and saline \pm notexin controls $\left({ }^{*} P<0 \cdot 05\right)$. (B) Differential circulating proinsulin (white bars)/insulin (black bars) levels at 14 days following plasmid injection. Percentages refer to proportion of proinsulin/insulin represented by fully processed insulin. (C) Serum human C-peptide at 14 days following plasmid injection. Mean circulating C-peptide was significantly higher in the hppl 1 and hppl1/notexin groups compared with saline \pm notexin controls $\left({ }^{\star} P<0 \cdot 05\right)$. alone although results did not reach statistical significance (Fig. 9A). Mean glucose level was significantly lower in the notexin/hppI1 group (Fig. 9B) compared with hppI1 alone and saline \pm notexin controls over the 14 days following plasmid injection (mean glucose: $7 \cdot 1 \mathrm{mmol} / \mathrm{l}$, $7 \cdot 3 \mathrm{mmol} / 1,7 \cdot 6 \mathrm{mmol} / 1$ respectively).

Notexin injection resulted in significant weight loss over the first $24 \mathrm{~h}$ sustained throughout the study (Fig. 9C). There was marginally increased weight gain following plasmid injection in the insulin gene groups relative to their saline-injected controls although this did not reach statistical significance.

Thirty-seven-day study of insulin expression following in vivo transfection with pIRES-hppI1 and pIRES-hppI4

Serum levels of human insulin following wild-type and mutant plasmid injection peaked at 7 days but persisted above base-line for 37 days with the highest levels at each time point in animals injected with pIRES-hppI4 (Fig. 10A). Serum human proinsulin concentrations at 37 days were low in all groups, suggesting $>80 \%$ proinsulin to insulin processing following in vivo transfection with wild-type and mutant plasmids (Fig. 10B). Overall rat + human insulin levels measured by rat insulin ELISA with 120-160\% cross-reactivity for human insulin were higher in plasmid compared with control groups (Fig. 10C).

The mean glucose level was significantly lower in the hppI1 group compared with the saline control over the 37 days following plasmid injection (saline $6.5 \mathrm{mmol} / \mathrm{l}$; hppI1 $6.37 \mathrm{mmol} / \mathrm{l}$; hppI4 $6.42 \mathrm{mmol} / \mathrm{l}(P<0 \cdot 05))$. Glycosylated haemoglobin at 37 days was significantly lower in the hppI1 and hppI4 groups compared with saline control (Fig. 10D). There were no significant differences in weight between plasmid and control saline-injected groups.

Macroscopic and histological examination of muscle and other tissues at completion of 14- and 37-day studies following plasmid injection showed no evidence of any abnormality.

In vivo transfection with pIRES-hppI1 and pIRES-hppI4 in mature rats

Overall human (pro)insulin levels were similar in wildtype and mutant injected groups but processing to mature insulin was increased in groups transfected with the mutant construct (Fig. 11A). Overall, circulating rat and human (pro)insulin measured by non-specific rat ELISA was high in all groups, suggestive of endogenous rat hyperinsulinaemia in these older animals which were allowed free access to dietary sucrose throughout (Fig. 11B). Lower levels were seen in animals which had received wild-type human insulin plasmid. This suggests that expression of human proinsulin with only $70 \%$ 
assay cross-reactivity may have resulted in inhibition of pancreatic rat insulin secretion.

There were no significant differences in blood glucose levels between groups prior to plasmid injection. At 10 days, mean glucose concentrations in the mutant plasmid-injected groups were significantly lower than in controls (Fig. 11C). There were no significant differences in weight in plasmid-injected compared with saline-injected rats.
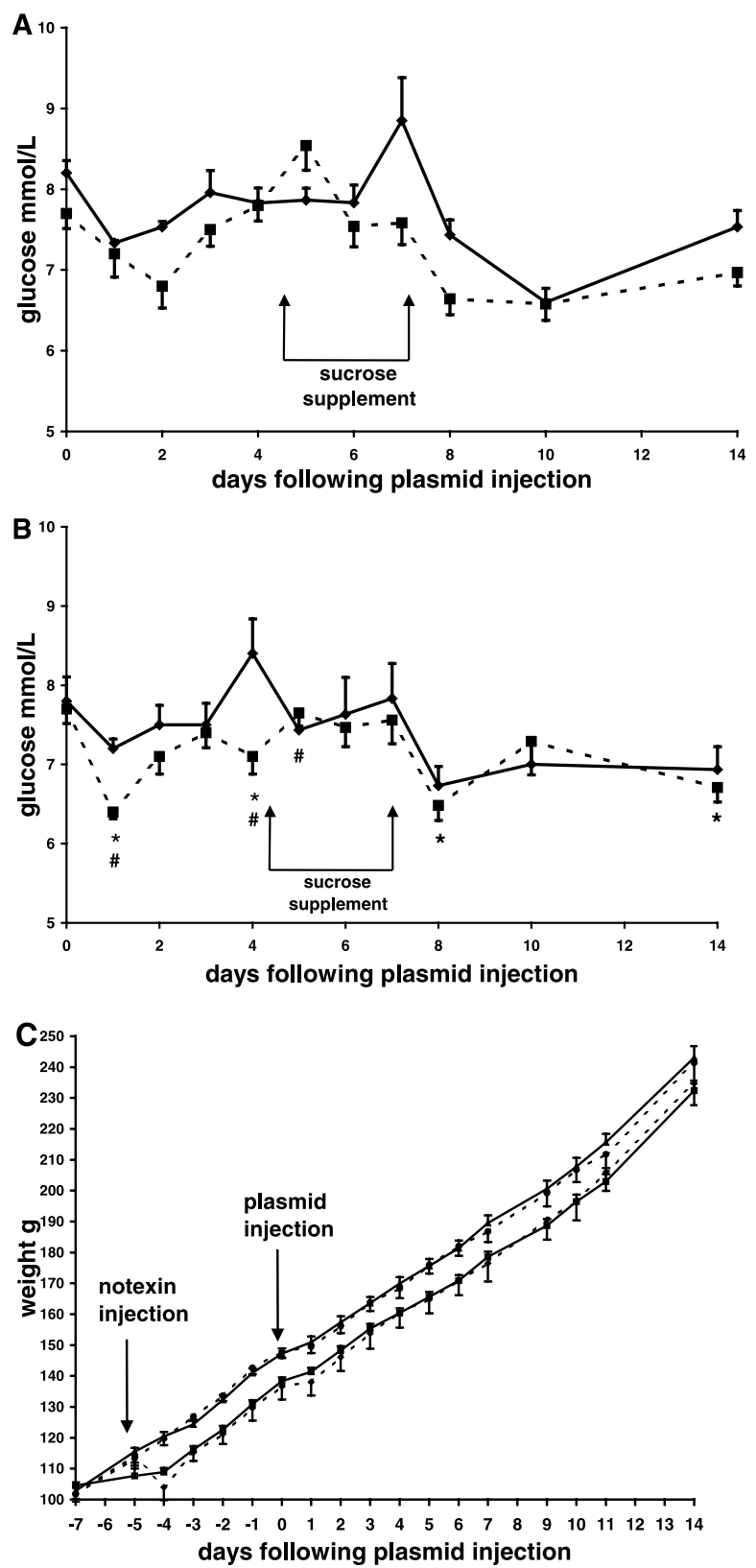

\section{Discussion}

Previous in vitro transfection studies in primary myoblasts and fibroblasts have highlighted inefficiency in comparison to transfected cell lines together with relative efficacy of Lipofectamine and resistance of myotubes to transfection, possibly due to absence of proliferation in these postmitotic end-differentiated cells (Green et al. 1991, Ray \& Gage 1992, Baum et al. 1994, Veelken et al. 1994, Trivedi \& Dickson 1995). Strong viral promoters such as $\mathrm{CMV}_{\text {ie }}$ have been shown to result in higher peak transgene expression than muscle-specific promoters in muscle cells transfected in vitro (Hagstrom et al. 2000). Higher peak levels and longer sustained levels of (pro)insulin secretion in adult dermal fibroblasts following addition of LLnL are in keeping with a series of studies performed in primary human fibroblasts and the HeLa fibroblast cell line (Trivedi \& Dickson 1995).

Lower overall levels of measured (pro)insulin secretion are common to many reported transfections of nonneuroendocrine cells with insulin constructs with mutated cleavage sites in comparison with wild-type insulin transfections (Yanagita et al. 1992, Simonson et al. 1996). The underlying cause remains unclear but low intracellular levels argue against a secretory defect. Increased metabolism of insulin in comparison with proinsulin may have contributed to lower overall (pro)insulin levels in mutant transfections. In FAO hepatoma cells incubated

Figure 9 Effect of insulin plasmid/notexin injection on glucose homeostasis and body weight. Notexin was injected 5 days before insulin plasmid/saline. Three animals were injected with $75 \mu \mathrm{l}$ saline, 3 with saline preceded by notexin, 12 with $75 \mu \mathrm{l}$ pIRES-hppl 1 and 12 with pIRES-hppl 1 preceded by notexin. All animals were allowed access to supplemental sucrose from days 4-7. Glucose was assayed and animals weighed daily. Values are means \pm S.E.M. with groups compared by one-way ANOVA. Notexin had no effect on circulating glucose. (A) Serum glucose in saline (solid line)/hppl1 (broken line) groups. Mean glucose level was lower than control at all but one time-point following hppl1 injection although differences did not reach statistical significance. (B) Serum glucose in saline (solid line)/hppl1 (broken line) pre-injected with notexin. Mean glucose level was significantly lower in the hppl1/notexin group compared with hppl1 alone $(\# P<0 \cdot 05)$ and saline \pm notexin controls $\left({ }^{*} P<0 \cdot 05\right)$ over the 14 days following plasmid injection $(7 \cdot 1 \mathrm{mmol} / \mathrm{l}, 7 \cdot 3 \mathrm{mmol} / \mathrm{l}$, $7 \cdot 6 \mathrm{mmol} / \mathrm{l}$ respectively). (C) Body weight following notexin and plasmid/saline injection (upper solid line, hppl1; upper broken line, saline; lower solid line, hppl1/notexin; lower broken line, saline/ notexin). Notexin resulted in a significant fall in body weight sustained throughout the study (saline/hppl1 vs saline/hppl1 + notexin $P<0 \cdot 05)$. There was marginally increased weight gain following plasmid injection in the insulin gene groups relative to their saline-injected controls although this did not reach statistical significance (mean weight over 14 days after plasmid injection: saline $185.5 \mathrm{~g}$ vs hppl1 $186.8 \mathrm{~g}$; saline/notexin $176.2 \mathrm{~g}$ vs hppl1/notexin 176.5 g). Differences were more marked prior to sucrose supplementation with maximal increase of $1.5 \mathrm{~g} /$ animal in the insulin gene group and $3.3 \mathrm{~g} /$ animal in the insulin group pre-treated with notexin. 
with radio-labelled rat proinsulin II or rat insulin-II, there was no proinsulin degradation but 15\% degradation of insulin was measured over $2 \mathrm{~h}$ (Vollenweider et al. 1992). Insulin uptake and degradation by other insulin receptorexpressing cells following binding would be envisaged,
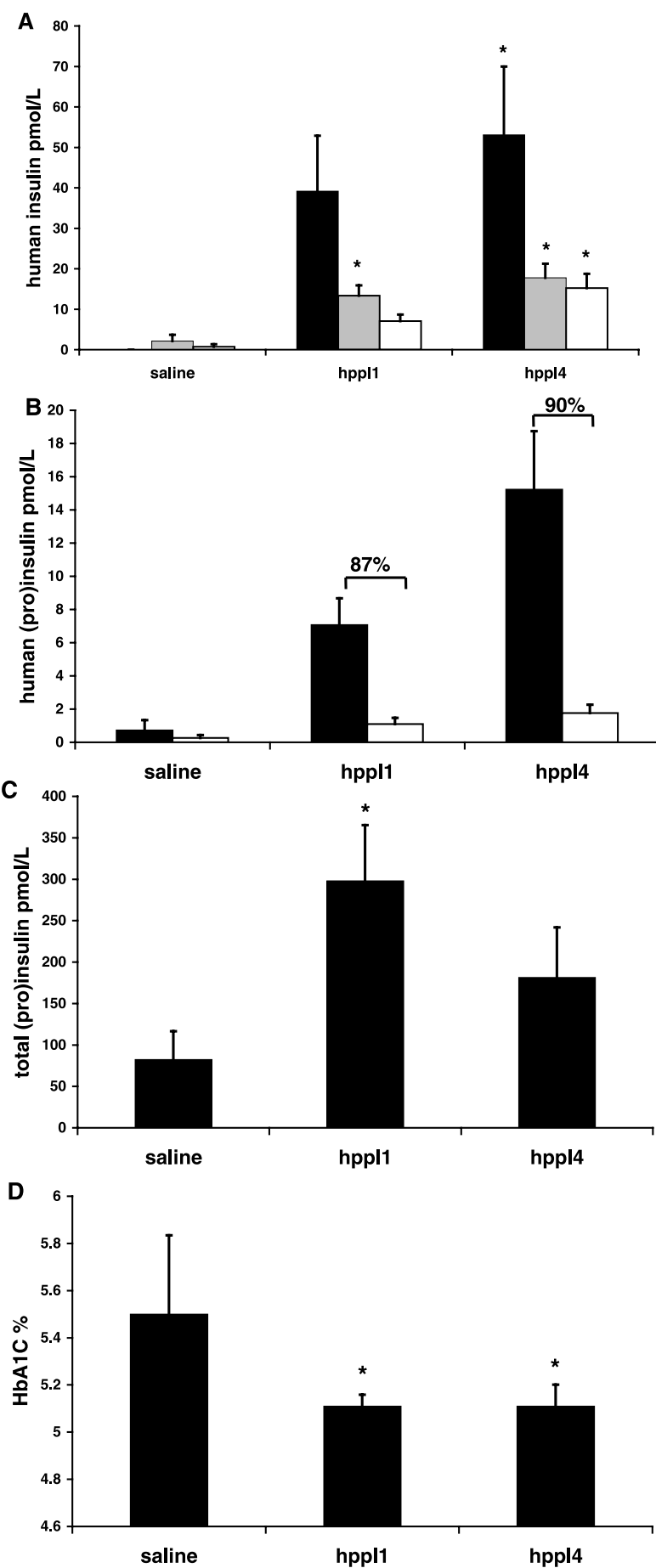

with relative stability of proinsulin due to decreased insulin receptor affinity (Podlecki et al. 1984, Duckworth et al. 1988, Backer et al. 1990).

The degree of (pro)insulin to insulin processing following transfection with human insulin plasmids is in keeping with transfections of fibroblast and hepatocyte cell lines with a wild-type rat insulin-I construct and a mutant construct encoding an altered B-chain/C-peptide junction to allow furin recognition (Nishigori et al. 1996). Percentage processing correlated with the level of endogenous furin expression and was increased to $100 \%$ on cotransfection of $\mathrm{CHO}$ cells with a furin gene construct. Carboxypeptidase $\mathrm{H}$ and other carboxypeptidases are expressed in non-neuroendocrine cells and completion of insulin processing by exoproteolytic removal of basic amino acids from the newly exposed B-chain has been confirmed on transfection with the mutant rat proinsulin-I construct (Groskreutz et al. 1994). In the only previously published work in primary rat myoblasts transfected with a human proinsulin construct engineered to express furin recognition sequences, mutations introduced a lysine to arginine point mutation, of unknown function or mitogenicity, at the penultimate B chain amino acid (B29) in mature insulin (Simonson et al. 1996). Expression and processing of hppI 4 , in contrast, yields unmodified human insulin.

Localised transgene expression following in situ skeletal muscle transfection is in keeping with previous studies (Acsadi et al. 1991). This has clearly been a major limiting factor preventing successful application of this technique to the treatment of primary muscle disorders such as Duchenne muscular dystrophy where dissemination to all affected fibres is of paramount importance. In applications requiring systemic secretion of therapeutic proteins,

Figure 10 (Pro)insulin/C-peptide expression and $\mathrm{HbA} 1 \mathrm{C}$ up to 37 days following plasmid injection. Four animals were injected with normal saline, 10 with pIRES-hppl 1 and 10 with pIRES-hppl 4 $(75 \mu \mathrm{l}$ per injection $(1 \mu \mathrm{g} / \mu \mathrm{l}))$. Blood was sampled for insulin ELISA at 7, 21 and 37 days following plasmid injection when the animals were killed. Values are means \pm S.E.M. (A) Serum expression of human insulin following plasmid injection. Mean circulating human insulin at 7 days (black bars), 21 days (grey bars) and 37 days (white bars) was significantly higher in the hppl4 group compared with saline controls (one-way ANOVA ${ }^{*} P<0.05$ vs control). In the hppl1 group, mean circulating human insulin was significantly higher than in controls at 21 days. (B) Differential circulating proinsulin (white bars)/insulin (black bars) levels at 37 days following plasmid injection. Percentages refer to proportion of proinsulin/insulin represented by fully processed insulin. (C) Total circulating insulin-like immunoreactivity. Overall insulin levels were significantly higher than controls in the pIRES-hppl1 group due to $160 \%$ assay cross-reactivity with expressed human insulin (one-way ANOVA ${ }^{*} P<0.05$ vs control). (D) HbA1C in whole blood samples collected terminally at 37 days post plasmid injection. Values are means \pm S.E.M. with groups compared by one-way ANOVA. HbA1C was significantly lower in hppl1 and hppl4 groups compared with saline control $\left({ }^{*} P<0 \cdot 05\right)$ (saline: 5.5\%; hppl1: 5·1\%; hppl4: 5.1\%). 

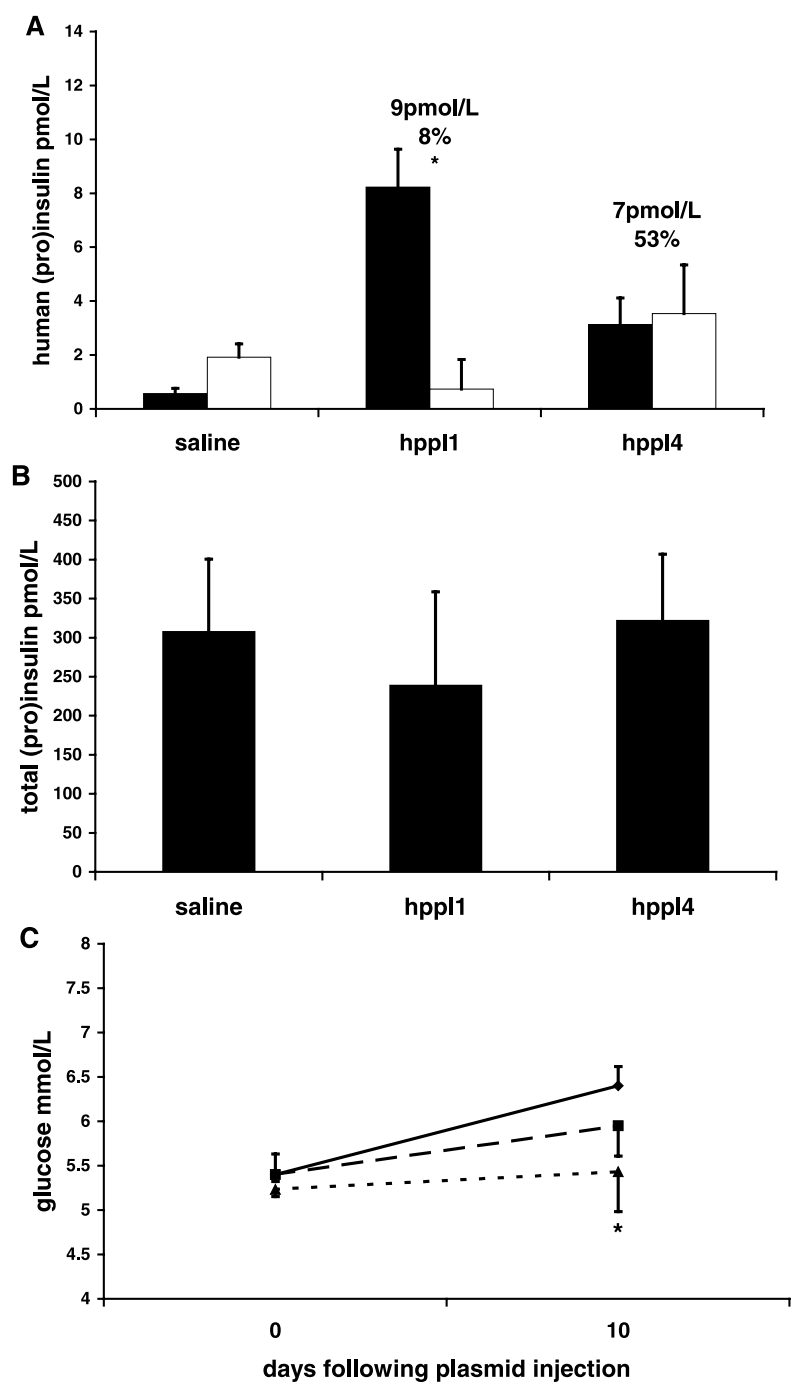

Figure 11 (Pro)insulin expression and glucose homeostasis in mature 9-month-old rats at 10 days following plasmid injection. Six animals were injected with normal saline, 6 with pIRES-hppl 1 and 6 with pIRES-hppl4 $(75 \mu \mathrm{l}$ per injection $(1 \mu \mathrm{g} / \mu \mathrm{l}))$. Animals were killed at 10 days. Values are means \pm S.E.M. (A) Serum expression of human (pro)insulin (black bars) and human insulin (white bars). Despite similar total (proinsulin + insulin) levels $\left({ }^{*} P<0.05\right.$ vs saline) differences in proinsulin to insulin processing were apparent (percentages refer to proportion of proinsulin/insulin represented by fully processed insulin). (B) Total circulating insulin-like immunoreactivity. Overall insulin levels were lower than controls in the pIRES-hppl 1 group possibly due to human proinsulin with only $70 \%$ crossreactivity compared with rat insulin (100\%) and human insulin (160\%). (C) Serum glucose levels. There were no significant differences in blood glucose levels between groups (saline: diamond; hppl1: square; hppl4: triangle) prior to plasmid injection. At 10 days, the mean level in the hppl4 plasmid-injected group was significantly lower than saline controls (one-way ANOVA *P<0.05). absence of foreign gene dissemination is, however, an advantage allowing surgical removal in the event of insulin-induced hypoglycaemia or other adverse event. In addition, muscle fibres are terminally differentiated avoiding the danger of hypoglycaemia due to proliferation of cells expressing the insulin transgene. The injected plasmid is maintained as an episome without replication or chromosomal integration and there is thus very little risk of insertional mutagenesis further enhancing the safety of this approach (Wolff et al. 1992).

Preliminary studies of intramuscular plasmid injection with a human preproinsulin adeno-associated viral vector construct under the control of a muscle-specific creatine kinase promoter have been reported (Bartlett et al. 1998). Circulating proinsulin levels in hamstring-injected nondiabetic rats were higher than in sham-injected rats persisting for 28 days, with highest levels seen in rats with streptozotocin-induced diabetes. A non-specific RIA was employed with cross-reactivity for rat and human proinsulin and insulin, and no glucose data were reported.

Plasmids expressing rat proinsulin-I, mutated at the B-chain/C-peptide and C-peptide/A-chain junctions to allow furin cleavage, together with a mouse furin DNA expression cassette have been administered to calf muscles of male BALB/c mice (Kon et al. 1999). Circulating (pro)insulin levels were determined by RIA with $100 \%$ cross-reactivity for mouse, rat and human insulin but low cross-reactivities of 5-10\% for proinsulin and split forms. Overall circulating (pro)insulin levels, measured from 7-21 days following plasmid injection, were higher in plasmid-injected mice with streptozotocin-induced diabetes in comparison with diabetic mice without plasmid injection, although levels remained lower than in nonstreptozotocin-treated non-plasmid-injected controls. Optimal results were achieved with $100 \mu \mathrm{g}$ of a CMVdriven insulin/furin plasmid injected in 2 separate sites 14 days prior to diabetes induction. Glucose levels measured at a single time-point were significantly lower in comparison with non-plasmid injected streptozotocindiabetic mice.

In a further study (Abai et al. 1999), BALB/c immunodeficient mice received tibialis anterior or rectus femoris injections with plasmids expressing rat proinsulin-I, rat proinsulin-I with a B10 aspartic acid mutation resulting in increased insulin secretion in transfected nonneuroendocrine cells including myoblasts (VR-3502), and a derivative of this with an additional engineered furin cleavage site at the B-chain/C-peptide junction (VR-3503). In initial in vivo studies in non-diabetic mice, serum proinsulin levels assessed by specific ELISA were consistently higher with the B10 aspartic acid substituted construct (VR-3502), and this was used in all subsequent studies. Tibialis anterior was the optimal injection site with maximal circulating proinsulin levels attained with $200 \mu \mathrm{g}$ DNA. Serum proinsulin levels fell dramatically beyond 2 weeks following plasmid injection and $75 \%$ of injected 
animals developed circulating antibodies to the B10 Asp rat proinsulin, although repeat plasmid administration at 8 weeks elicited similar maximal proinsulin levels and pattern of decline. Plasmid administration in athymic nude mice resulted in elevation of circulating proinsulin levels for at least 6 weeks. Streptozotocin induction of consistent absolute-insulin deficiency in nude mice proved difficult and was associated with significant mortality. Injection of the mutated proinsulin construct (VR-3503) together with a furin construct or a control DNA construct containing plasmid-backbone but no expressed gene at the time of streptozotocin injection resulted in similarly elevated blood glucose from 3-5 days with an abrupt fall in glucose thereafter in both groups. Ultimately, all control injected animals died or required euthanasia by day 7 . Blood glucose in the active treatment group had risen again to diabetic levels by day 10 , when the initial plasmid injection was repeated in 9 surviving animals from an initial 15 injected. There were 3 further deaths following the second plasmid injection, with glucose falling to normal levels for the following 7 days in surviving mice. No circulating (pro)insulin levels were reported in this study. At 32 days, (pro)insulin was detectable in tissue extracted from both injected tibialis anterior muscles, but levels were lower than in pancreatic extracts indicating significant recovery of endogenous $\beta$-cell function.

The present studies are the first to describe plasmidmediated muscle-targeted in vivo gene delivery using a human insulin plasmid engineered to enable secretion of fully processed unmodified human insulin following furin cleavage. The B10 aspartic acid substitution has been avoided in view of concerns surrounding its mitogenic potential, evidenced by induction of mammary tumour formation in susceptible rats, leading to withdrawal from clinical trials. Employment of pIRES bicistronic expression vectors may have contributed to efficient translation due to the presence of a synthetic intron downstream of the cloned insulin sequence known to increase RNA stability, resulting in increased cytoplasmic RNA accumulation (Huang \& Gorman 1990a). In addition, the soleus muscle has been targeted for plasmid injection, having a high proportion of type 1 slow-twitch muscle fibres and thus a higher overall protein synthesis rate in contrast to more commonly targeted fast-twitch muscles such as tibialis anterior (Huang \& Gorman 1990a).

The potential for enhancing (pro)insulin secretion by induction of myolysis prior to insulin plasmid injection has not previously been described. Notexin is derived from the venom of the Australian tiger snake Notechis scutatus (Dixon \& Harris 1996) and has been successfully employed to augment myoblast allotransplantation in a Simian model of muscular dystrophy (Kinoshita et al. 1995). It leaves the microcirculation, satellite cells and basal lamina intact leading to vigorous muscle regeneration. It may thus result in more efficient transgene expression following naked DNA injection than alternative myolytic agents, mediated by uptake of injected plasmid by activated satellite cells with subsequent incorporation into actively regenerating multinucleated fibres.

Decreased transgene expression in older animals, as seen in the mature rat study, has been described previously (Goldspink et al. 1994). This is thought to reflect an increased capacity for DNA uptake in rapidly growing young muscle fibres.

A high degree of variability in transgene expression was witnessed in all studies. This is characteristic of this approach and remains incompletely explained, although it has been suggested that the use of higher injection volumes (Davis et al. 1994) or concomitant in vivo electroporation may minimise variation (Mir et al. 1999). The effect of notexin-induced myolysis was also variable, with the significantly higher mean circulating insulin levels in the reported 24-h pilot study being due to a markedly elevated concentration in a single animal.

The use of highly sensitive and specific ELISAs allowed discrimination between transgene-expressed human and endogenous rat (pro)insulin together with evaluation of post-translational modification in vivo. Apparent high levels of proinsulin to insulin processing in young rats transfected in vivo with both pIRES-hppI1 and pIREShppI4 were unexpected, given the in vitro processing rates in primary myoblast cultures. Partial cleavage to des 31,32 proinsulin following in vivo transfection with the wild-type plasmid would escape detection by both proinsulin and insulin ELISAs which do not cross-react with this intermediate. In the FAO hepatoma cell line transfected in vitro with a wild-type human preproinsulin gene, a degree of processing to mature insulin was seen with the highest proportion of total secreted ILI attributable to des 31,32 proinsulin (Mir et al. 1999).

In contrast, percentage processing determined by differential ELISAs in mature rats following in vivo gene transfer is comparable to that seen in myoblasts in vitro with both the wild-type and mutant construct, raising the possibility of increased expression of furin or other processing enzymes in fused myofibres in young animals in vivo.

Although other studies have included experiments in streptozotocin-diabetic animals and the possibility of glucose-regulated (pro)insulin secretion has been suggested, data on the glycaemic effect of this approach to insulin gene delivery remain extremely limited. In the present studies in non-diabetic animals, significantly lower blood glucose levels were attainable in plasmid-injected animals without symptomatic hypoglycaemia. Moreover, glycosylated haemoglobin levels confirmed significantly lower overall glycaemic exposure in both wild-type and plasmid-injected animals over 37 days. HbA1C determination has been shown to provide a meaningful measure of medium term glycaemia in rats (De et al. 1996), but has not been previously reported in studies of muscle-targeted insulin delivery. Confirmation of transgenic insulin 
bioactivity provides further evidence for significant post-translational processing of expressed proinsulin.

The ultimate goal of diabetic gene therapy would be reinstatement of glucose-regulated insulin secretion, and constitutive insulin delivery has previously been dismissed as a therapeutic option in diabetes due to concerns over hypoglycaemia. Studies with insulin infusion pumps have, however, confirmed the efficacy of basal insulin delivery as a sole treatment in Type 2 diabetes (Blackshear et al. 1985) and in conjunction with preprandial insulin boluses in Type 1 diabetes (Bode et al. 1996), being associated with less hypoglycaemia than conventional insulin therapy. In these studies, constitutive insulin secretion exerted a significant hypoglycaemic effect without progression to dangerous hypoglycaemia, providing further validation of the potential of this approach for diabetes treatment.

Successful clinical application of plasmid-mediated muscle-targeted insulin gene delivery may provide an elegant, highly patient-acceptable and cost-effective therapy for Type 2 diabetes, offering the potential of glycaemic control sufficient to prevent long-term diabetic complications with a low incidence of hypoglycaemia from a simple infrequent intramuscular injection and avoiding the need for immunosuppression. Moreover, attainment of relatively low levels of constitutive insulin secretion could be employed as a 'depot' treatment in the prevention of recurrent keto-acidosis in insulin-omitting adolescents with Type 1 diabetes, a group in which mortality remains unacceptably high despite all currently available interventions (Laing et al. 1999). Intramuscular insulin gene delivery may also have a role as a DNA 'vaccination' to facilitate $\beta$-cell rest and immune tolerisation in the hope of facilitating the ultimate goal of prophylaxis of Type 1 diabetes.

Small molecule transcriptional regulation of insulin gene expression employing a tetracycline-responsive promoter which would allow the level of insulin secretion to be regulated or 'switched off' by oral administration of tetracycline as an important safety feature (Dhawan et al. 1995). Ultimately, it may be possible to attain glucoseresponsivity at the transcriptional level by cloning a glucose-regulatable promoter upstream of the insulin gene. Restoration of glucose-responsive insulin secretion by transfected endogenous hepatocytes has been attained in rats with streptozotocin-induced diabetes following adenovirus-mediated in vivo transfer of a rat preproinsulin I gene, mutated to facilitate furin cleavage, under the control of a modified hepatic glucose 6-phosphatase promoter (Chen et al. 2001) and in NOD mice following systemic injection of an adeno-associated viral vector expressing a single chain insulin analogue, mediating comparable bioactivity to mature insulin without posttranslational modification, under the control of the hepatocyte-specific pyruvate kinase promoter (Lee et al. 2000). Reduced insulin requirement in insulin-dependent $\mathrm{BB}$ rats and an attenuated hyperglycaemic response to intraperitoneal glucose challenge has been demonstrated on reimplantation of syngeneic vascular smooth muscle cells infected ex vivo with a retrovirus encoding a glucose-regulatable transforming growth factor $\alpha$ promoter controlling furin expression and a viral promoter driving constitutive expression of furin-cleavable human proinsulin (Barry et al. 2001). Rapid regulated secretion of pre-formed insulin, previously thought unattainable in non-neuroendocrine cells, may also be possible. This has been demonstrated in a transfected human fibrosarcoma cell line following implantation in streptozotocin-diabetic mice, allowing insulin secretion and the associated fall in serum glucose within $15 \mathrm{~min}$ of administration of a specific ligand (Rivera et al. 2000).

In conclusion, constitutive secretion of human (pro)insulin has been attained in non-neuroendocrine cell lines, primary rat myoblasts and dermal fibroblasts transfected with a wild-type human preproinsulin insulin plasmid and a mutant construct engineered to facilitate furin cleavage. Significant processing to mature bioactive insulin was confirmed following in vitro transfection with the mutant construct. Sustained systemic secretion of human insulin has been demonstrated in young and mature rats following in vivo transfection of hind-limb soleus muscle with wild-type and mutant insulin plasmids by single intramuscular injection. Foreign DNA remained localised with no evidence of dissemination outwith the injected muscle. The choice of plasmid vector and injection site may have contributed to transfection efficiency, which was further enhanced by the novel use of notexin as a myolytic agent. Insulin was bioactive exerting a glucose lowering effect without dangerous hypoglycaemia. Further development of these techniques may lead to muscle-targeted gene therapy for diabetes by simple intramuscular injection of ex vivo engineered host-derived myoblasts, dermal fibroblasts with subsequent myogenic conversion, or naked plasmid DNA avoiding the need for immunosuppression.

\section{Acknowledgements}

Dr J A M Shaw was supported by a Clinical Research Fellowship from the Medical Research Council. Dr A W Hart was supported by a Biotechnology and Biological Sciences Research Council research studentship.

\section{References}

Abai AM, Hobart PM \& Barnhart KM 1999 Insulin delivery with plasmid DNA. Human Gene Therapy 10 2637-2649.

Acsadi G, Dickson G, Love DR, Jani A, Walsh FS, Gurusinghe A, Wolff JA \& Davies KE 1991 Human dystrophin expression in $\mathrm{mdx}$ mice after intramuscular injection of DNA constructs. Nature $\mathbf{3 5 2}$ 815-818.

Backer JM, Kahn CR \& White MF 1990 The dissociation and degradation of internalized insulin occur in the endosomes of rat hepatoma cells. Journal of Biological Chemistry 265 14828-14835. 
Barry SC, Ramesh N, Lejnieks D, Simonson WT, Kemper L, Lernmark A \& Osborne WR 2001 Glucose-regulated insulin expression in diabetic rats. Human Gene Therapy 12 131-139.

Bartlett RJ, Denis M, Secore SL, Alejandro R \& Ricordi C 1998 Toward engineering skeletal muscle to release peptide hormone from the human pre-proinsulin gene. Transplantation Proceedings $\mathbf{3 0}$ 451

Baum C, Forster P, Hegewisch-Becker S \& Harbers K 1994 An optimized electroporation protocol applicable to a wide range of cell lines. Biotechniques 17 1058-1062.

Berger M 1996 To bridge science and patient care in diabetes. Diabetologia 39 749-757.

Blackshear PJ, Shulman GI, Roussell AM, Nathan DM, Minaker KL, Rowe JW, Robbins DC \& Cohen AM 1985 Metabolic response to three years of continuous, basal rate intravenous insulin infusion in type II diabetic patients. Journal of Clinical Endocrinology and Metabolism 61 753-760.

Bode BW, Steed RD \& Davidson PC 1996 Reduction in severe hypoglycemia with long-term continuous subcutaneous insulin infusion in type I diabetes. Diabetes Care 19 324-327.

Chen R, Meseck ML \& Woo SL 2001 Auto-regulated hepatic insulin gene expression in type 1 diabetic rats. Molecular Therapy 3 584-590.

Coonrod A, Li FQ \& Horwitz M 1997 On the mechanism of DNA transfection: efficient gene transfer without viruses. Gene Therapy 4 1313-1321.

Dai Y, Roman M, Naviaux RK \& Verma IM 1992 Gene therapy via primary myoblasts: long-term expression of factor IX protein following transplantation in vivo. PNAS 89 10892-10895.

Davis HL, Michel ML, Mancini M, Schleef M \& Whalen RG 1994 Direct gene transfer in skeletal muscle: plasmid DNA-based immunization against the hepatitis B virus surface antigen. Vaccine 12 1503-1509.

De Tata V, Novelli M, Bombara M, Masiello P, Cappuccio A, Innocenti B \& Bergamini E 1996 Determination of glycated hemoglobins in the rat: comparison between two different chromatographic methods and application in experimental diabetology. Research in Experimental Medicine 196 9-16.

Dhawan J, Pan LC, Pavlath GK, Travis MA, Lanctot AM \& Blau HM 1991 Systemic delivery of human growth hormone by injection of genetically engineered myoblasts [see comments]. Science 254 1509-1512.

Dhawan J, Rando TA, Elson SL, Bujard H \& Blau HM 1995 Tetracycline-regulated gene expression following direct gene transfer into mouse skeletal muscle. Somatic Cell and Molecular Genetics 21 233-240.

Dixon RW \& Harris JB 1996 Myotoxic activity of the toxic phospholipase, notexin, from the venom of the Australian tiger snake. Journal of Neuropathology and Experimental Neurology $\mathbf{5 5}$ 1230-1237.

Duckworth WC, Peavy DE, Hamel FG, Liepnieks J, Brunner MR, Heiney RE \& Frank BH 1988 Conversion of biosynthetic human proinsulin to partially cleaved intermediates by collagenase proteinases adsorbed to isolated rat adipocytes. Biochemical Journal 255 277-284.

Falqui L, Martinenghi S, Severini GM, Corbella P, Taglietti MV, Arcelloni C, Sarugeri E, Monti LD, Paroni R, Dozio N, Pozza G \& Bordignon C 1999 Reversal of diabetes in mice by implantation of human fibroblasts genetically engineered to release mature human insulin. Human Gene Therapy 10 1753-1762.

Gazdar AF, Chick WL, Oie HK, Sims HL, King DL, Weir GC \& Lauris V 1980 Continuous clonal insulin and somatostatin secreting cell lines established from a transplantable rat islet cell tumour. PNAS 77 3519-3523.

Gibson AJ, Karasinski J, Relvas J, Moss J, Sherratt TG, Strong PN \& Watt DJ 1995 Dermal fibroblasts convert to a myogenic lineage in mdx mouse muscle. Journal of Cell Science 108 207-214.
Goldspink G, Fernandes K, Williams PE \& Wells DJ 1994 Age-related changes in collagen gene expression in the muscles of mdx dystrophic and normal mice. Neuromuscular Disorders 4 183-191.

Green MH, Lowe JE, Teufel R \& Petit-Frere C 1991 Reducing the concentration of selected marker improves efficiency of cotransfer of unselected DNA into SV40-transformed human fibroblasts. Experimental Cell Research 192 298-301.

Groskreutz DJ, Sliwkowski MX \& Gorman CM 1994 Genetically engineered proinsulin constitutively processed and secreted as mature, active insulin. Journal of Biological Chemistry 269 6241-6245.

Hagstrom JN, Couto LB, Scallan C, Burton M, McCleland ML, Fields PA, Arruda VR, Herzog RW \& High KA 2000 Improved muscle-derived expression of human coagulation factor IX from a skeletal actin/CMV hybrid enhancer/promoter. Blood $\mathbf{9 5}$ 2536-2542.

Higuchi R, Krummel B \& Saiki RK 1988 A general method of in vitro preparation and specific mutagenesis of DNA fragments: study of protein and DNA interactions. Nucleic Acids Research 16 $7351-7367$.

Horton HM, Anderson D, Hernandez P, Barnhart KM, Norman JA \& Parker SE 1999 A gene therapy for cancer using intramuscular injection of plasmid DNA encoding interferon alpha. PNAS 96 $1553-1558$.

Huang MT \& Gorman CM 1990a Intervening sequences increase efficiency of RNA $3^{\prime}$ processing and accumulation of cytoplasmic RNA. Nucleic Acids Research 18 937-947.

Huang MTF \& Gorman CM $1990 b$ Intervening sequences increase efficiency of RNA 3' processing and accumulation of cytoplasmic RNA. Nucleic Acids Research 18 937-947.

Jang SK, Krausslich HG, Nicklin MJ, Duke GM, Palmenberg AC \& Wimmer E 1988 A segment of the $5^{\prime}$ nontranslated region of encephalomyocarditis virus RNA directs internal entry of ribosomes during in vitro translation. Journal of Virology 62 2636-2643.

Jones GE, Murphy SJ \& Watt DJ 1990 Segregation of the myogenic cell lineage in mouse muscle development. Journal of Cell Science $\mathbf{9 7}$ 659-667.

Kawakami Y, Yamaoka T, Hirochika R, Yamashita K, Itakura M \& Nakauchi H 1992 Somatic gene therapy for diabetes with an immunological safety system for complete removal of transplanted cells. Diabetes 41 956-961.

Kinoshita I, Vilquin JT, Gravel C, Roy R \& Tremblay JP 1995 Myoblast allotransplantation in primates. Muscle Nerve $\mathbf{1 8}$ 1217-1218.

Kleinman HK, McGarvey ML, Liotta LA, Robey PG, Tryggvason K \& Martin GR 1982 Isolation and characterization of type IV procollagen, laminin, and heparan sulfate proteoglycan from the EHS sarcoma. Biochemistry 21 6188-6193.

Kon OL, Sivakumar S, Teoh KL, Lok SH \& Long YC 1999 Naked plasmid-mediated gene transfer to skeletal muscle ameliorates diabetes mellitus. Journal of Gene Medicine 1 186-194.

Laing SP, Swerdlow AJ, Slater SD, Bothat JL, Burden AC, Waugh NR, Smith AW, Hill RD, Bingley PJ, Patterson CC, Qiao Z \& Keen H 1999 The British Diabetic Association Cohort Study, II: cause-specific mortality in patients with insulin-treated diabetes mellitus [see comments]. Diabetes Medicine 16 466-471.

Lee HC, Kim SJ, Kim KS, Shin HC \& Yoon JW 2000 Remission in models of type 1 diabetes by gene therapy using a single-chain insulin analogue. Nature 408 483-488.

Mir L, Bureau MF, Gehl J, Rangara R, Rouy D, Caillaud JM, Delaere P, Branellec D, Schwartz B \& Scherman D 1999 High-efficiency gene transfer into skeletal muscle mediated by electric pulses. PNAS 96 4262-4267.

Miyazaki J, Araki K, Yamato E, Ikegami H, Asano T, Shibasaki Y, Oka Y \& Yamamura K 1990 Establishment of a pancreatic beta cell line that retains glucose-inducible insulin secretion: special reference to expression of glucose transporter isoforms. Endocrinology 127 $126-132$ 
Nishigori T, Yanagita M \& Takeuchi T 1996 Proinsulin cleaved by furin is processed to chromatographically mature insulin by carboxypeptidases in non neuroendocrine cells. Peptides 17 789-796.

Petrof BJ, Acsadi G, Bourdon J, Matusiewicz N \& Yang L 1996 Phenotypic and immunologic factors affecting plasmid-mediated in vivo gene transfer to rat diaphragm. American Journal of Physiology 270 L1023-L1030.

Podlecki DA, Frank BH \& Olefsky JM 1984 In vitro characterization of biosynthetic human proinsulin. Diabetes 33 111-118.

Pullar JD \& Webster AJF 1979 The energy cost of fat and protein deposition in the rat. British Journal of Nutrition 37 355-363.

Ray J \& Gage FH 1992 Gene transfer into established and primary fibroblast cell lines: comparison of transfection methods and promoters. Biotechniques 13 598-603.

Richler C \& Yaffe D 1970 The in vitro cultivation and differentiation capacities of myogenic cell lines. Developmental Biology 23 1-22.

Rivera VM, Wang X, Wardwell S, Courage NL, Volchuk A, Keenan T, Holt DA, Gilman M, Orci L, Cerasoli F Jr, Rothman JE \& Clackson T 2000 Regulation of protein secretion through controlled aggregation in the endoplasmic reticulum [see comments]. Science $287826-830$

Shaw JAM \& Docherty K 1999 Gene therapy for type 2 diabetes: will it have a role? In Type 2 Diabetes: Prediction and Prevention, pp 367-381. Ed. GA Hitman. Chichester, UK: Wiley.

Simonson GD, Groskreutz DJ, Gorman CM \& MacDonald MJ 1996 Synthesis and processing of genetically modified human proinsulin by rat myoblast primary cultures. Human Gene Therapy 7 71-78.

Stewart C, Taylor NA, Green IC, Docherty K \& Bailey CJ 1994 Insulin-releasing pituitary cells as a model for somatic cell gene therapy in diabetes mellitus. Journal of Endocrinology 142 339-343.

Stewart M 1990 Intermediate filaments: structure, assembly and molecular interactions. Current Opinion in Cell Biology 2 91-100.

Sutherland DER 1993 Pancreatic transplantation: an update. Diabetes Review 1 152-165.

Tames FJ, Baird JD \& Bone AJ $1990 \mathrm{HbA} 1$ in assessment of metabolic control in diabetic BB/E rats. Diabetologia 33 257-261.

The Diabetes Control and Complications Trial Research Group 1993 The effect of intensive treatment of diabetes on the development and progression of long-term complications in insulin-dependent diabetes mellitus. New England Journal of Medicine 329 977-986.

Tripathy SK, Svensson EC, Black HB, Goldwasser E, Margalith M, Hobart PM \& Leiden JM 1996 Long-term expression of erythropoietin in the systemic circulation of mice after intramuscular injection of a plasmid DNA vector. PNAS 93 10876-10880.

Trivedi RA \& Dickson G 1995 Liposome-mediated gene transfer into normal and dystrophin-deficient mouse myoblasts. Journal of Neurochemistry 64 2230-2238.
UK Prospective Diabetes Study Group 1998 Intensive blood-glucose control with sulphonylureas or insulin compared with conventional treatment and risk of complications in patients with type 2 diabetes. Lancet 352 837-853.

Veelken H, Jesuiter H, Mackensen A, Kulmburg P, Schultze J, Rosenthal F, Mertelsmann R \& Lindemann A 1994 Primary fibroblasts from human adults as target cells for ex vivo transfection and gene therapy. Human Gene Therapy 5 1203-1210.

Vollenweider F, Irminger JC, Gross DJ, Villa-Komaroff L \& Halban PA 1992 Processing of proinsulin by transfected hepatoma (FAO) cells. Journal of Biological Chemistry 267 14629-14636.

Wachtler F \& Christ B 1992 The basic embryology of skeletal muscle formation in vertebrates: the avian model. Seminars in Developmental Biology 3 217-227.

Wang R, Doolan DL, Le TP, Hedstrom RC, Coonan KM, Charoenvit Y, Jones TR, Hobart P, Margalith M, Ng J, Weiss WR, Sedegah M, de Taisne C, Norman JA \& Hoffman SL 1998 Induction of antigen-specific cytotoxic $\mathrm{T}$ lymphocytes in humans by a malaria DNA vaccine. Science 282 476-480.

Weintraub H, Davis R, Tapscott S, Thayer M, Krause M, Benezra R, Blackwell TK, Turner D, Rupp R \& Hollenberg S 1991 The myoD gene family: nodal point during specification of the muscle cell lineage. Science 251 761-766.

Weir GC \& Bonner-Weir S 1997 Scientific and political impediments to successful islet transplantation. Diabetes 46 1247-1256.

Weiss RA 1998 Transgenic pigs and virus adaptation. Nature 391 327-328.

Wells DJ 1995 Intramuscular injection of plasmid DNA. In Molecular and Cell Biology of Human Gene Therapentics, pp 83-103. Ed. G Dickson. Cambridge, UK: Chapman and Hall.

Weykamp CW, Penders TJ, Miedema K, Muskiet FA \& van der Slik W 1995 Standardization of glycohemoglobin results and reference values in whole blood studied in 103 laboratories using 20 methods. Clinical Chemistry 41 82-86.

Wolff JA, Ludtke JJ, Acsadi G, Williams P \& Jani A 1992 Long-term persistence of plasmid DNA and foreign gene expression in mouse muscle. Human and Molecular Genetics 1 363-369.

Worsey MJ \& Williams PA 1977 Characterization of a spontaneously occurring mutant of the TOL20 plasmid in Pseudomonas putida MT20: possible regulatory implications. Journal of Bacteriology 130 $1149-1158$.

Yanagita M, Nakayama K \& Takeuchi T 1992 Processing of mutated proinsulin with tetrabasic cleavage sites to bioactive insulin in the non-endocrine cell line, COS-7. FEBS Letters 311 55-59.

Received 12 July 2001

Accepted 2 October 2001 